\title{
IS THAT REALLY THE END, OR WHAT HAPPENED IN THE CIVIL TOWN OF AQUINCUM IN THE FOURTH CENTURY AD?
}

\author{
ORSOLYA LÁNG
}

\author{
Aquincum Museum and Archaeological Park \\ 135 Szentendrei út, H-1031 Budapest, Hungary \\ lang.orsolya@aquincum.hu
}

\begin{abstract}
The last period at the Aquincum Civil Town has long been a matter of dispute. Earlier researchers presumed a fourth century occupation phase at the settlement. However, re-examining these previous data (including an inscription, a coin hoard, walls, coins and several other finds of excavation contexts and even the "dark-earth" phenomenon) and analyzing the results of recent researches show that there is an obvious paucity of Late Roman finds. What is more, these results even show that most of them turn out to be third century finds. Based on the above mentioned, we can get to the conclusion, that the latest observable period in the Civil Town falls in the middle-end of the third century, or to the beginning of the fourth century at latest. Such an early abandonment of the Aquincum Civil Town is not unparalleled among Pannonian and other Western Roman provincial towns. And why was the Aquincum Civil Town abandoned relatively early? The reasons might be sought in the, by that time, already deteriorated fortifications and the loss of markets. No further (systematic) use could be demonstrated here in layers, finds, or constructions. Nevertheless, since a few fourth century finds still occur, the possibility cannot be excluded that certain areas were still sporadically used, particularly when buildings were mainly mined for spolia.
\end{abstract}

Keywords: Aquincum, settlement, Civil Town, abandonment, sources, finds, coins, old data, research

\section{THE END OF THE CIVIL TOWN - WRITTEN AND VISUAL SOURCES}

Only very scarce data can be found in antique written sources concerning the latest - fourth to fifth century history of the Aquincum settlement complex. One of the writers mentioning Aquincum is Ammianus Marcellinus. He describes the town, already in ruins in the last quarter of the fourth century: “(...) nullaque sedes idonea reperiri (...) poterat". ${ }^{1}$ Nevertheless, since Ammianus was describing the ineffective search for appropriate winter accomodation for Emperor Valentinianus in Aquincum, this quote most probably refers either to the buildings of the canabae or the legionary fortress itself. ${ }^{2}$ In contrast, nearly a hundred years later (AD 458), Sidonius Apollinaris refers to Aquincum ("Acinco") as a flourishing, military settlement: "Fertur, Pannoniae qua Martia pollet Acincus (...)". But again, judging from the text itself, this description refers to the military centre of what was by then province Valeria, namely the Late Roman fortress and the Military Town of Aquincum. ${ }^{4}$ Ennodius, working in the second half of the fifth century, mentions a certain Valeria civitas where - based on the story of a certain Antonius - a Christian community existed at that time. ${ }^{5}$ Its identification, however, with Aquincum (which part?) is far from certain. ${ }^{6}$ Concerning contemporary visual data, the Tabula Peutingeriana, most likely dated to the fourth-fifth century, marks Aquincum

${ }^{1}$ Ammianus Marcellinus, 30.5.13-14.

${ }^{2}$ A. Alföldi also identifies the area, together with the fortress (though possibly with the second-third century fortress, since the Late Roman fortress was only discovered decades later): ALFÖLDI 1942, 727.

${ }^{3}$ Sidonius Apollinaris, V. Paneg. Maioriano Augusto.

${ }^{4}$ PócZY-Zsidi 2003, 65. L. Nagy also interprets Sidonius Apollinaris's words as referring to the canabae: L. NAGY 1942, 774.
${ }^{5}$ Ennodius, Vita beati Antoni 7.

${ }^{6}$ Identifies with Aquincum: PócZY-ZsIDI 2003, 65. Identifies Civitas Valeria with a settlement in Dacia Ripensis, thus, also noting that there is no evidence for provincials still living in Aquincum in this period: То́тн 2009, 185-186.

Acta Archaeologica Academiae Scientiarum Hungaricae 69 (2018) 143-168 0001-5210 @ 2018 Akadémiai Kiadó, Budapest 
(Aquinco) with a two-towered building as a "third-level" city (the pictogram used for provincial capitals or important commercial centres) ${ }^{7}$, but since the settlement's military and administrative centre was located in and around the Late Roman fortress at that time, the pictogram could again be connected to that zone, rather than the Civil Town. The Late Roman (end of fourth-beginning of fifth century) State handbook, the Notitia Dignitatum, mentions Acinco, ${ }^{8}$ though its identification with Aquincum is problematic ${ }^{9}$. The only epigraphic evidence referring to Aquincum as a functioning municipal structure in the fourth century dates to AD 307 although it was in fact found in the canabae (see below). ${ }^{10}$

As seen above, unfortunately, no contemporary text or depiction can be securely associated with later life at the Civil Town itself. Still, a few Post-Roman period data are available that could shed some light on what remained of the town and how it might have looked by the time it was finally abandoned. Perhaps, the earliest datum comes from the early modern Italian military engineer, Marsigli: his map (based on his site surveys made in 1699) was published in 1726. The map showed a schematic, rectangular plan of the Civil Town together with its fortifications (and those of the legionary fortress at the centre of the Military Town). ${ }^{11}$ (Fig. 1) The row of the pillars of the main, North-South running aqueduct - a structure that also served as a land boundary maker in the fourth century ${ }^{12}$ - is also depicted. Marsigli described the civil settlement's remains as being "built of sand and bricks covered with earth". ${ }^{13}$ A few decades later, another engineer, Matthey, drew a similar map of the Civil Town. By that time, however, he could also show the clearly visible remains of both amphitheatres and the fortified area of the springs feeding the aqueduct, located north of the Civil Town, by the present-day Roman Bath. ${ }^{14}$ Later travellers such as R. Towson ${ }^{15}$ and Carlo Piño Vasques ${ }^{16}$ also depicted these architectural elements. The first detailed description of the the Roman remains of Óbuda (including the Civil Town) comes from Sándor Németh in 1823. He describes both the civilian amphitheatre and the remains of a, by that time still visible, large (!) building lying close to the northern town gate. ${ }^{17} \mathrm{~A}$ further, very picturesque description of what was still visible of the town's ruins by the last decades of the nineteenth century, comes from Flóris Rómer: “ (...) classicus area, whose ditches and bulges indicate traces of Roman streets, squares and, houses" and "(...) we have been walking on the Szentendrei Road made of Roman bricks, fragments of Samian ware, fresco and stucco decorations for years". ${ }^{18}$ In parallel with the beginning of the pioneer excavations at the Civil Town in the last quarter of the nineteenth century, the Hungarian painter Árpád Feszty captured the forum in 1894: architectural elements, segment of the main north-south road paved with stone slabs $^{19}$ and half a metre high walls of the so-called curia are depicted ${ }^{20}$. (Fig. 2) Based on the depictions and descriptions of the authors and artists from the middle of the eighteenth century onwards listed above, it is sure that the remains of the Civil Town never disappeared completely and in some cases survived in fairly good condition even after the Roman era (see e.g. the fortifications and the aqueduct). The relatively low height of the building walls could partially be the result of (Late Roman?), medieval and later stone robbery ${ }^{21}$ but is mainly due to the fact that most of the buildings' walls (particularly the private ones) were only partially constructed from stone: the foundations were constructed from limestone using either the opus incertum or opus spicatum technique while excavation data has shown that the rising walls were made of the more sensitive sun-dried clay bricks. ${ }^{22}$ None of our sources mentioned above record traces of destruction or signs of violence connected the ruins of the Civil Town.

\section{THE END OF THE TOWN'S LIFE - HISTORY OF RESEARCH}

The Civil Town of Aquincum has been the subject of archaeological research for the last 120 years. Since the first nineteenth century excavators mainly concentrated on unearthing complete ground plans of buildings, no attention was paid to layers and stratigraphy so that now the town's earliest and latest phases remain unclear. The

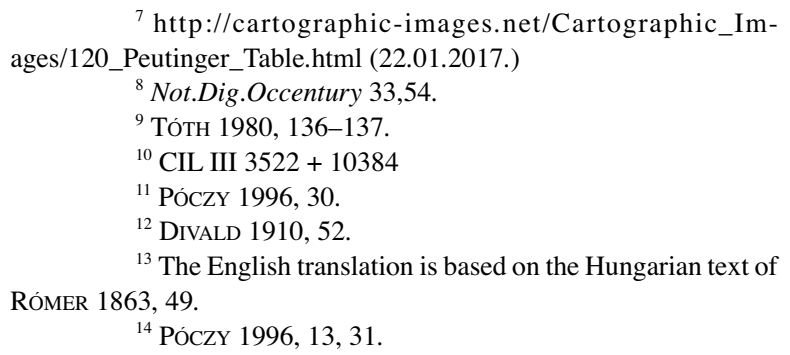

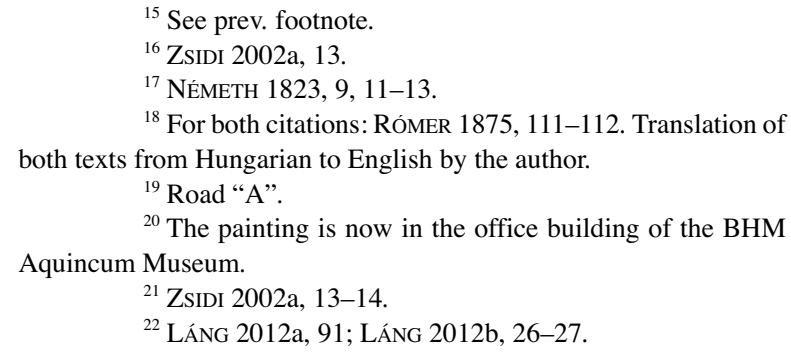




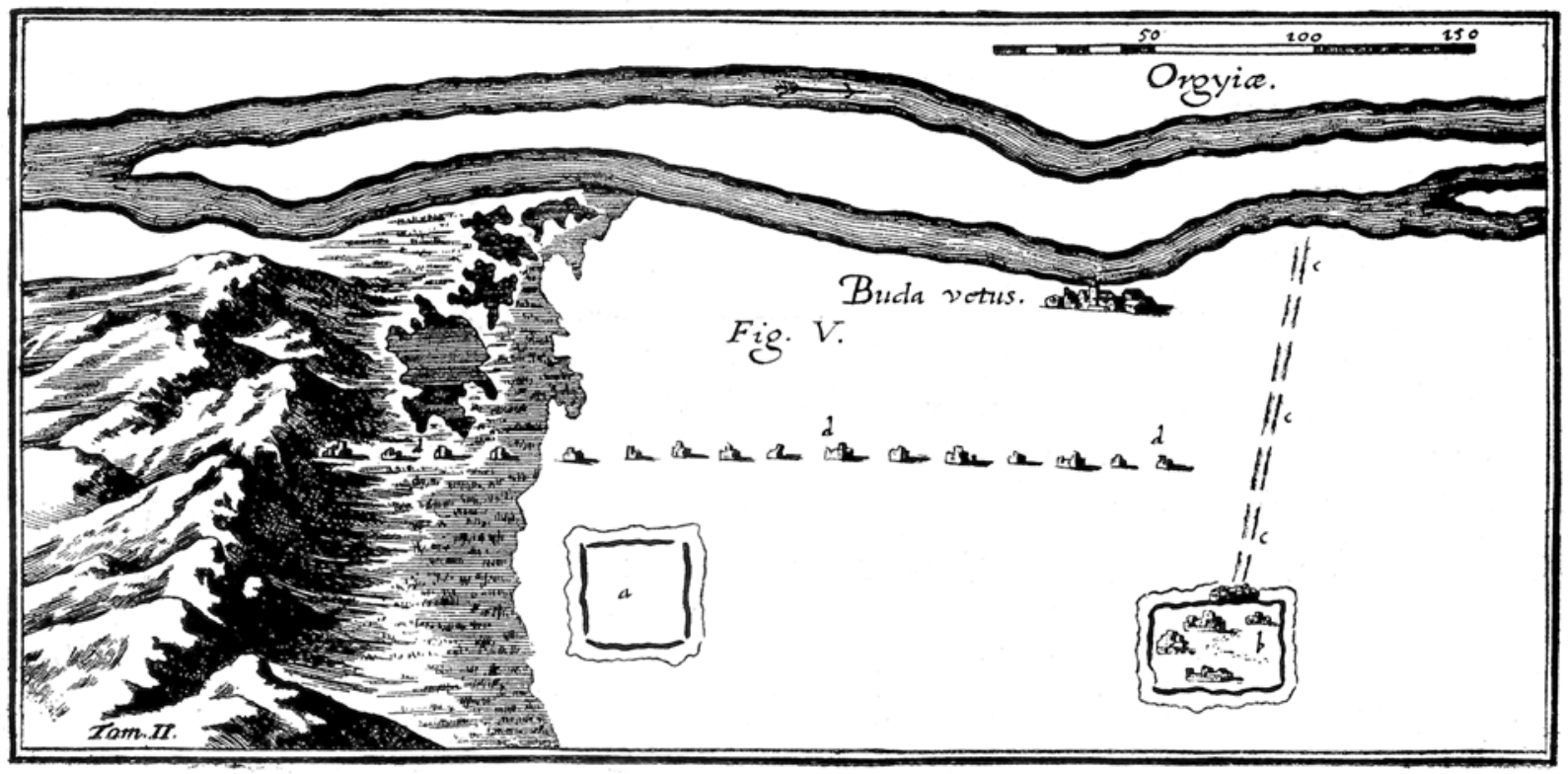

Fig. 1. Map of Marsigli with his depiction of the settlement complex of Aquincum (after Póczy 1996, 30)

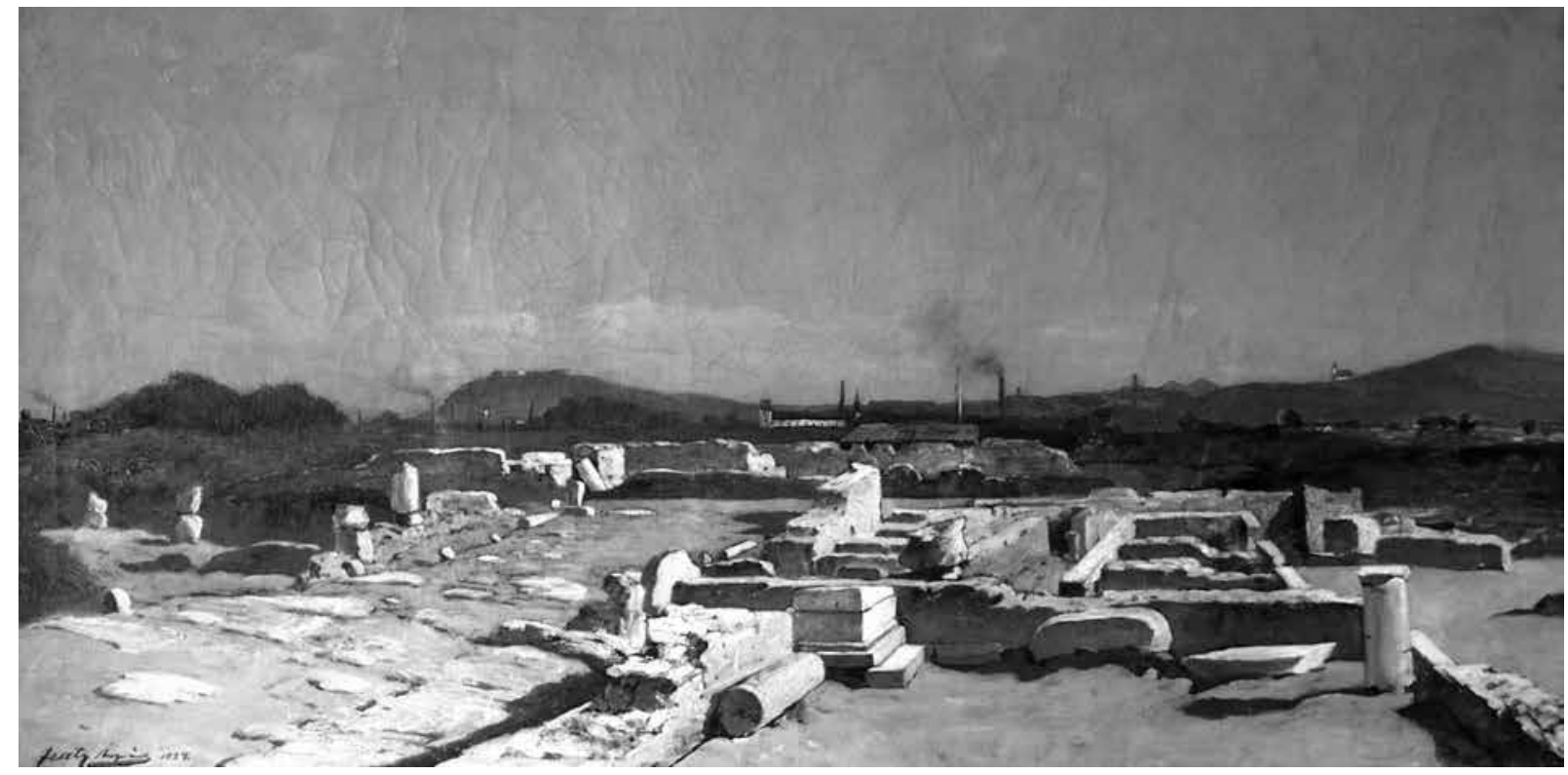

Fig. 2. Painting depicting the remains of the Civil Town viewed from the north by Árpád Feszty in 1894. Painting: BHM Aquincum Museum

first archaeologist to consider the last period of the buildings in the civil settlement was Bálint Kuzsinszky. According to Kuzsinszky, the so-called Victorinus mithraeum could have been "buried by AD 375", based on a 80-piece coin hoard he discovered there. He observed that the latest coin in the hoard was a coin of Flacilla (AD 379-395). ${ }^{23}$ The hoard was dug into the debris of the sanctuary, more than a $1 \mathrm{~m}$ higher (!) than the level of the cella. ${ }^{24}$ (Fig. 3) According to him, the houses were already uninhabited for about 60 years. ${ }^{25}$ Kuzsinszky described the so-called Great Bath as having fourth century finds, nevertheless these were not described in detail. ${ }^{26}$ next footnote.

${ }^{23}$ The earliest coin dated to the reign of Constantius II. See

${ }^{24}$ KUZSINSZKY 1889, 85-86.
${ }^{25}$ KUZSINSZKY 1934, 25-26.

${ }^{26}$ Op.cit. 37. No furher data attest the presence of any fourth century finds. 


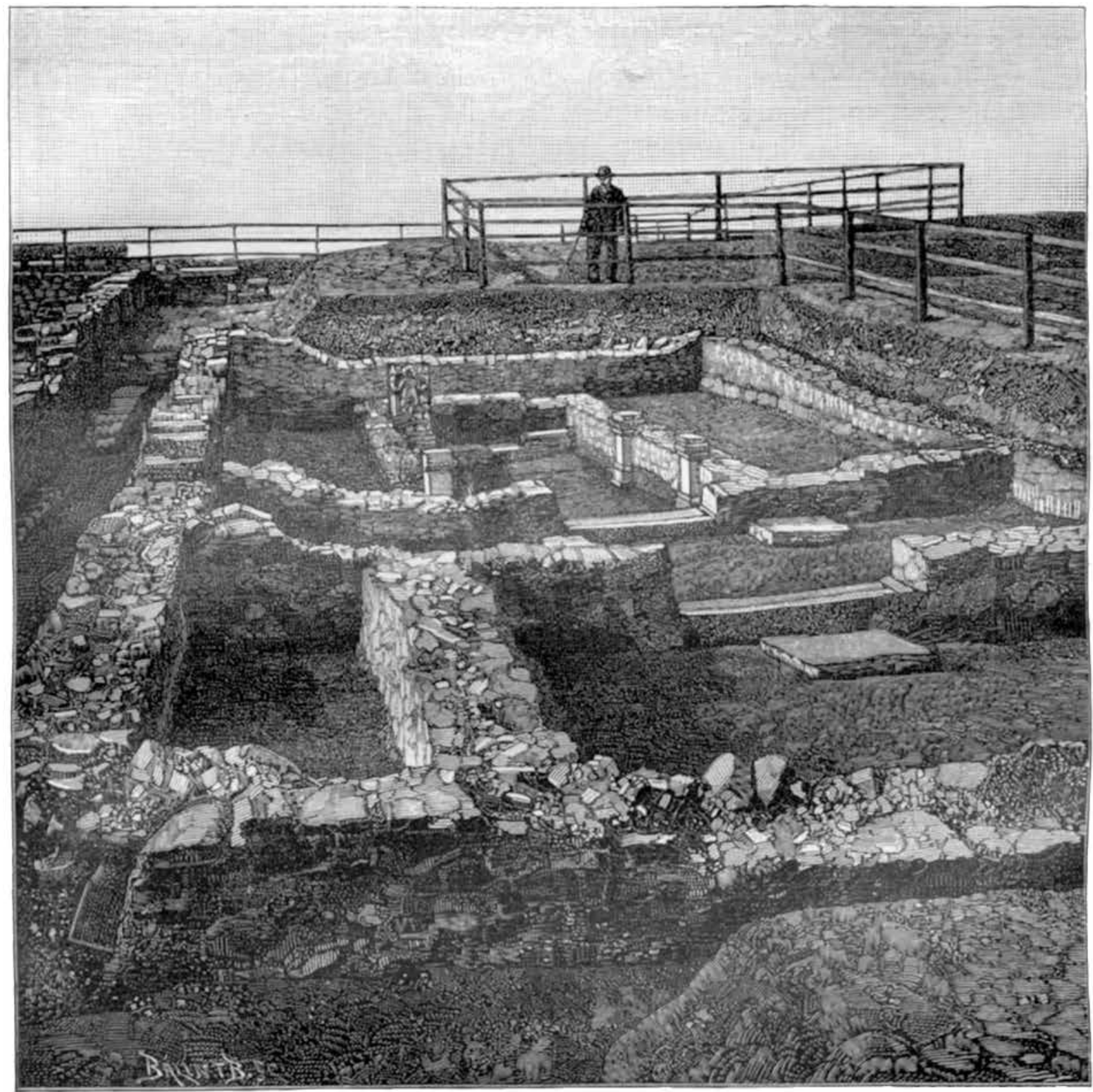

Fig. 3. The so-called Victorinus mithraeum as excavated by B. Kuzsinszky in 1887-88 (after KuzsinszKy 1889, 68, fig. 5)

A couple of decades later, Lajos Nagy - excavating both inside and outside the settlement - made several statements concerning the latest phase of the town. Even though not supported by any securely datable finds, L. Nagy identified "weak buildings with adobe walls from the fourth century AD" located south of the macellum. ${ }^{27}$ He basically considered the town deserta romanorum by the end of the fourth century - its inhabitants moving to the much safer canabae. He also noted that "no finds, not even meaningless potsherds have been found in the Civil Town so far that proved the continuity of Roman lifeways here".${ }^{28}$ The only well attested, late buildings excavated by him were the so-called "Double basilica" and a small chapel with an apsidial end and a cemetery around it, could be dated to the beginning of the fourth century. These structures were all located east of the Civil Town, on the banks

\footnotetext{
${ }^{27}$ LÁNG-NAGY-VÁMOS 2014, 16.
}

${ }^{28}$ L. NAGY 1942, 771. Translation of the original Hungarian text by the author. 


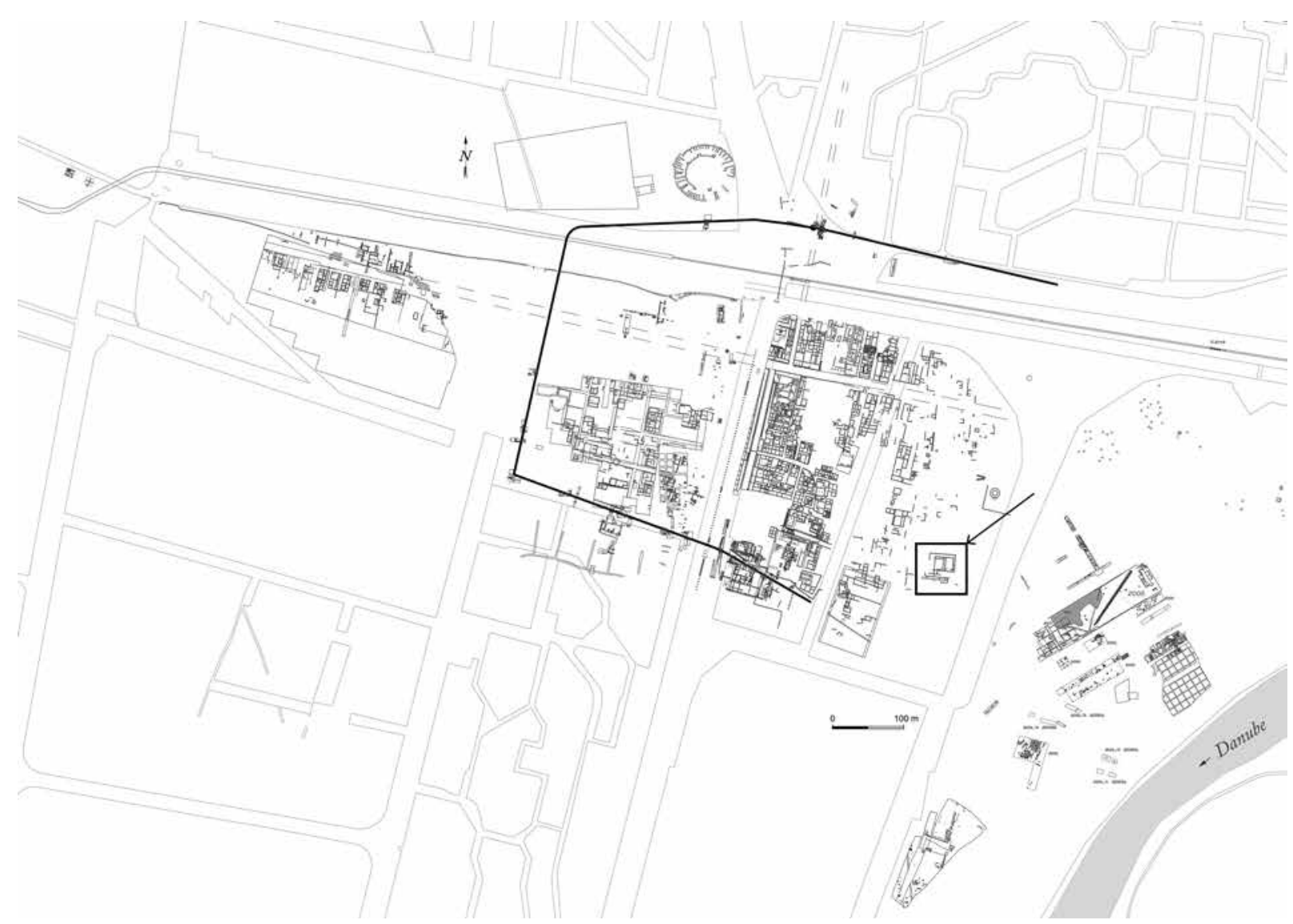

Fig. 4. Plan of the Civil Town with locations of the so-called Double Basilica and the chapel. (Drawing: K. Kolozsvári)

of the Danube. ${ }^{29}$ (Fig. 4) Roughly at the same time, András Alföldi wrote about houses "crumbling everywhere" in the Civil Town. ${ }^{30}$ Although he also reported fourth century renovations of roads, these works were rather connected to the forts at either Campona, Albertfalva or Aquincum. ${ }^{31}$

The next researcher dealing with the last period of the Civil Town was Tibor Nagy. This scholar based his statements on his excavation observations. Excavating in and around the so-called Symphorus Mithraeum next to the southern town wall, he found a cicada brooch in the "topmost, fourth century layer, $-76 \mathrm{~cm}$ below the latest pavement" in one of the buildings ${ }^{32}$ north of the mithraeum. ${ }^{33}$ (Fig. 5) Based on this ornamental find he assumed that renovations continued in the building at the beginning of the fourth century. Concerning the mithraeum itself, he dated the second (and last) phase of the sanctuary to the beginning of the third century and in his opinion, the building stood until the end of the fourth century (but gives no data on the final abandonment/destruction of the sanctuary).$^{34}$ According to T. Nagy, the settlement's fortifications and houses were renovated south of the macellum during the Constantine dynasty and also notes that there are no traces of industrial activity and neither were collegia functioning in the fourth century settlement. ${ }^{35} \mathrm{He}$ also refers to the inscription dated between AD $305-308,{ }^{36}$ con-

${ }^{29}$ Op.cit. 767-770. More recently on the basilica: Póczy 2000, 22-23. On the cemetery and the chapel: MADARASSY-TOPÁLZsIDI 2000, 32. For their role in the topography of Aquincum, see below.

${ }^{30}$ ALFÖLDI 1942, 726

${ }^{31}$ Milestones: CIL III 3709, 10626, 10656.

${ }^{32}$ The precise findspot is unknown.

${ }^{33}$ NAGY 1943, 389. Translation of the original Hungarian text by the author. He also deals with the cicada brooch in a manuscript written in the mid-1970s. T. NAGY: Aquincum és Kelet Pannonia statusa az V. század első felében [The status of Aquincum and
Eastern Pannonia in the first half of the fifth century BHM - AA H25271-2013].

${ }^{34}$ NAGY 1942, 433; NAGY 1943, 386. Three coins of Constantinus I were also found here, though the excavator does not mention them: inv.no. 56.200.125 (follis AE3, dated to 319), 128 (follis AE3, dates to 316-317), 130/4 (follis AE3, dated to 313). Control excavations by P. Zsidi in 2011 did not provide more information on the abandonment of the sanctuary either: ZSIDI 2002b, 47.

${ }^{35}$ NAGY 1973, 122, 137, 146.

${ }^{36}$ CIL III 3522+10384. 

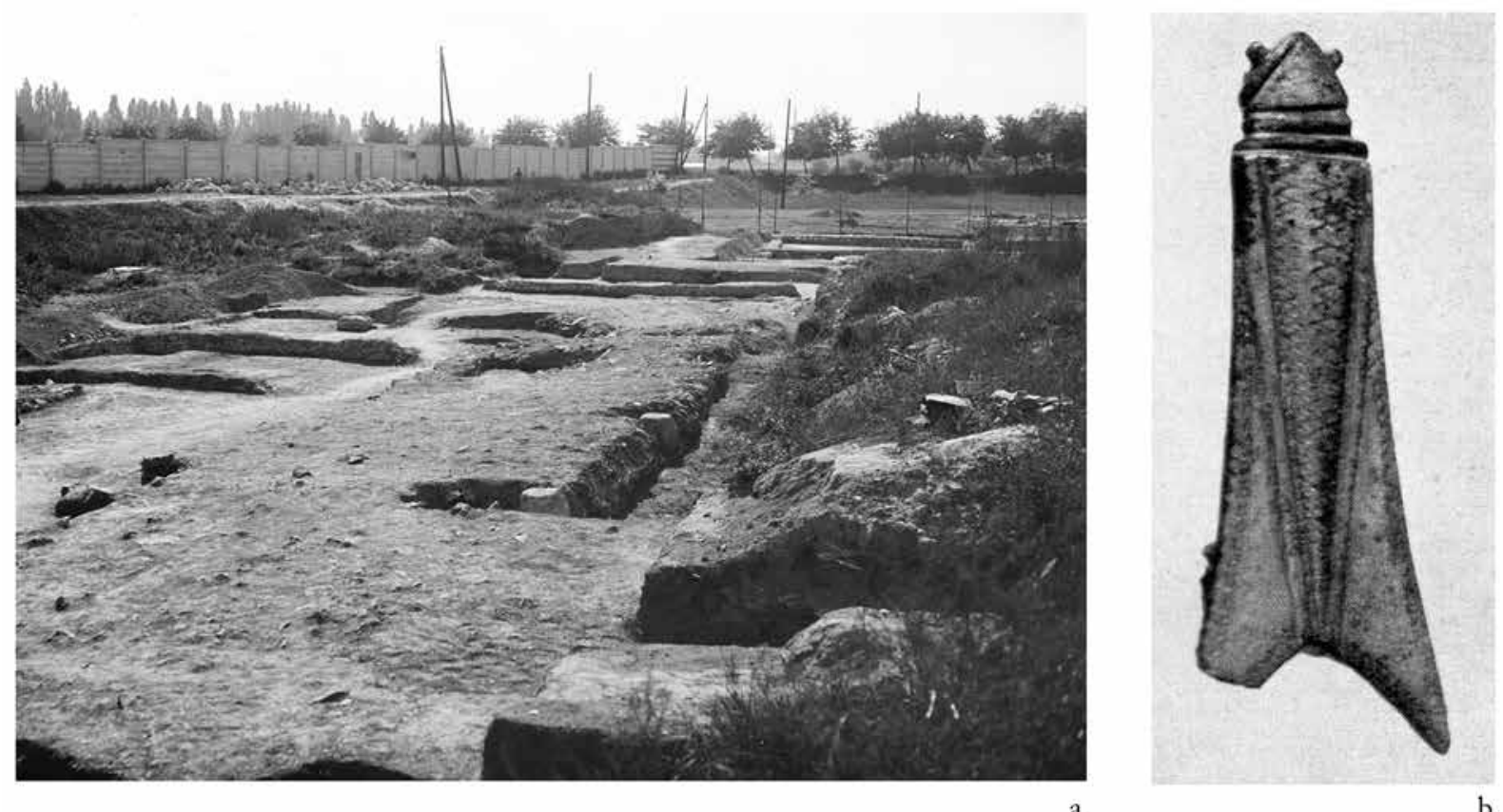

Fig. 5. Excavation area north of the Symphorus Mithraeum in 1941 and the cicada brooch found here (after NAGY 1943, 383, fig. 28 and BHM Aquincum Museum, Collection of Photos)

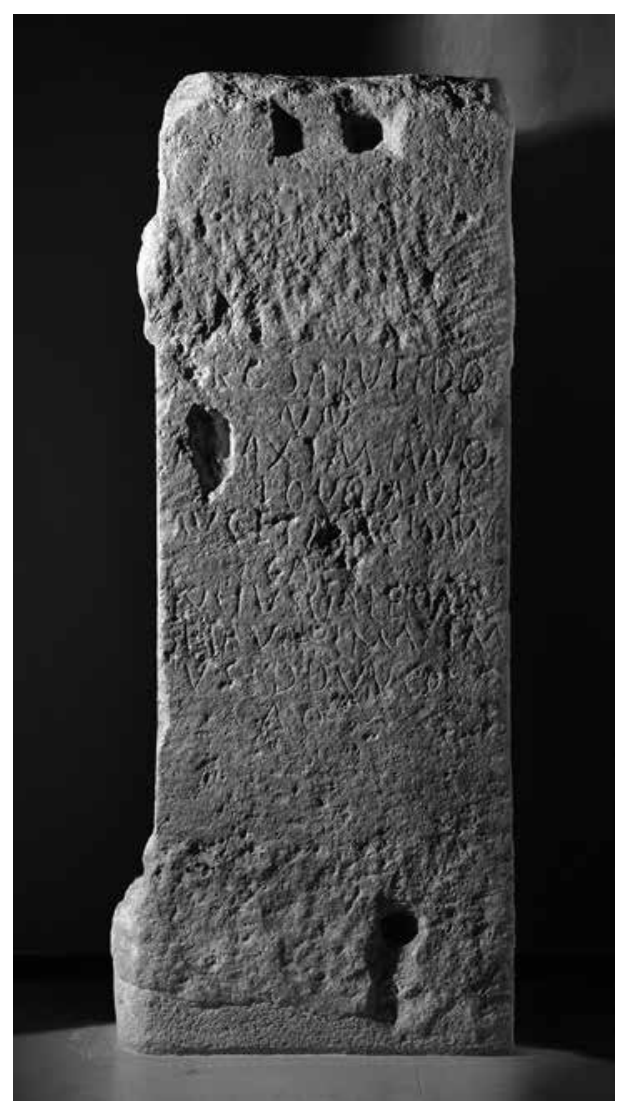

Fig. 6. Altar stone mentioning the duoviri of the colonia between AD 305-308

(Photo: Roman Collection of the Hungarian national Museum, courtesy Hungarian National Museum) 
taining the last mention of the duoviri of the colonia. The findspot of the stone (Military Town) raises the possibility that the seat of the town council was moved to the canabae. ${ }^{37}$ (Fig. 6) T. Nagy also suggested that the town was uninhabited after AD 378, and the finds that characterize this period "ovens made with mud, grey vessels with smoothed-in decoration and large cicada brooches" already indicate the presence of a "non-urban" population. T. Nagy believed that only a small settlement-core could be mentioned that developed east of the Civil Town, around the so-called Gázgyár watch-tower and that could be dated to the last decades of the fourth century. ${ }^{38}$

Klára Póczy - one of the most important researchers in the Civil Town from the 1950s onwards - dealt with the last period of the Civil Town in her numerous studies. On one hand, she also repeats previous research results, such as the aforementioned inscription that represented the last reference to municipal life in Aquincum ${ }^{39}$ and also refers to the presence of the Early Christian (Double) basilica and the cemetery at the Gas Factory area, in use between AD 340 and $378 .^{40}$ (Fig. 7) On the other hand, she considered that marble altar slabs also reflected the presence of Christians in the settlement (mainly in private houses) ${ }^{41}$ She believed the Civil Town's public buildings and the aqueduct were still being repaired in the first third of the fourth century ${ }^{42}$ and while the centre of the settlement may still have been inhabited in this century, the peripheral insulae would already have lain in ruins. ${ }^{43}$ She also hypothesized that the town must have been abandoned gradually around the end of the fourth-beginning of the fifth century, without any trace of destruction or fire. ${ }^{44} \mathrm{~K}$. Póczy also noted that information concerning the fourth century history of the Civil Town are very scarce and even if all fourth century-pavements were removed during the nineteenth century, some late Roman finds should still have remained in the museum's collections. However, she connects late finds excavated in the pottery workshop of the Gas factory area to a Barbarian population living East of the Civil Town, forming the garrison of the fourth century watchtower excavated nearby. ${ }^{45}$ Where else did inhabitants live in the surroundings of the Civil Town in the fourth century? Excavating the so-called Békásmegyer villa, $\mathrm{K}$. Póczy came to the conclusion that many villa estates continued to be used in the nearby Buda hills during the fourth century. Their inhabitants may also have taken an active part in the protection of the limes while the villae themselves served as defensive structures. ${ }^{46}$

More recently, Paula Zsidi carried out numerous researches concerning late life at the civilian settlement. She also notes that archaeological evidence between the fourth and the nineth centuries is "sparse and heterogeneous". Most artifacts derive from graves. ${ }^{47}$ While she also refers to the above-mentioned inscription dated to the beginning of the fourth century, she also presumed a decline in the population. ${ }^{48}$ Her innovative suggestion has been that while the easten part of the town may have been abandoned, the western part was re-fortified - its eastern fortification being the aquaeduct with its arches walled in - and continued to be inhabited. ${ }^{49}$ She based her idea on her excavations on the western part of the southern town wall, where a coin of Constantius II was discovered below a fallen segment of the town wall that collapsed into the half-filled late fossa. ${ }^{50}$ (Fig. 8) The latter discovery led her to the conclusion that the fortifications - or at least its southern part - were renovated after the middle of the fourth century AD. ${ }^{51}$ Further data suggesting the late use of certain areas in the western part of the settlement include an oven built of stone (of unknown date) attached to a building along the main East-West road and a pit filled with horse bones that cut through the Roman layers here. ${ }^{52}$ She also listed the forum, the so-called basilica, the Great Baths as well as the row of tabernae along the main North-South road - namely, buildings running along the two main roads of the settlement - that were still being renovated in the fourth century. ${ }^{53}$ No typical fourth century pottery finds (absence of glazed ware) came to light during her excavations in the building of the collegium centonariorum. Thus (?) she dates the last phase of the building to a time before the second third of the fourth century. ${ }^{54}$

${ }^{37}$ NAGY 1973, 125.

${ }^{38}$ Op. cit. 123. Translation of the original Hungarian text by the author. The findspot of the ovens and ceramic vessels are unknown.

${ }^{39}$ Póczy 1998, 63. See also T. Nagy's opinion about the find: previous page.

${ }^{40}$ PócZY 1964, 66-67.

${ }^{41}$ Póczy 2004, 199. No further information is given on the findspot or context of such altars.

${ }^{42}$ Op. cit. 165 . She also mentions an underground channel running west of the previous construction that was constructed in later Roman times to replace the aqueduct: Póczy 2003, 146.

${ }^{43}$ PócZY 1967, 151-154.
${ }^{44}$ PÓCZY 2004, 203-204.

${ }^{45}$ PÓCZY 1964, 68-69.

${ }^{46}$ PÓCZY 1971, 96-99.

${ }^{47}$ ZSIDI 1997-1998, 587, 589.

${ }^{48}$ ZSIDI 2002a, 119.

${ }^{49}$ ZsIDI 1990, 163; ZsIDI 1994, 218.

${ }^{50}$ Op. cit. 152.

${ }^{51}$ ZSIDI 2004, 204-205.

${ }^{52}$ ZSIDI 1984, 461; ZSIDI 1997-1998, 588.

${ }^{53}$ ZSIDI 2002a, 121; PÓCZY 2003, 148. The excavators (M. Németh and Gy. Hajnóczi) mention the last renovation works dated to the middle of the third century: NÉMETH-HAJNÓCZI 1976, 423. ${ }^{54}$ ZSIDI 1998, 92.

Acta Archaeologica Academiae Scientiarum Hungaricae 69, 2018 

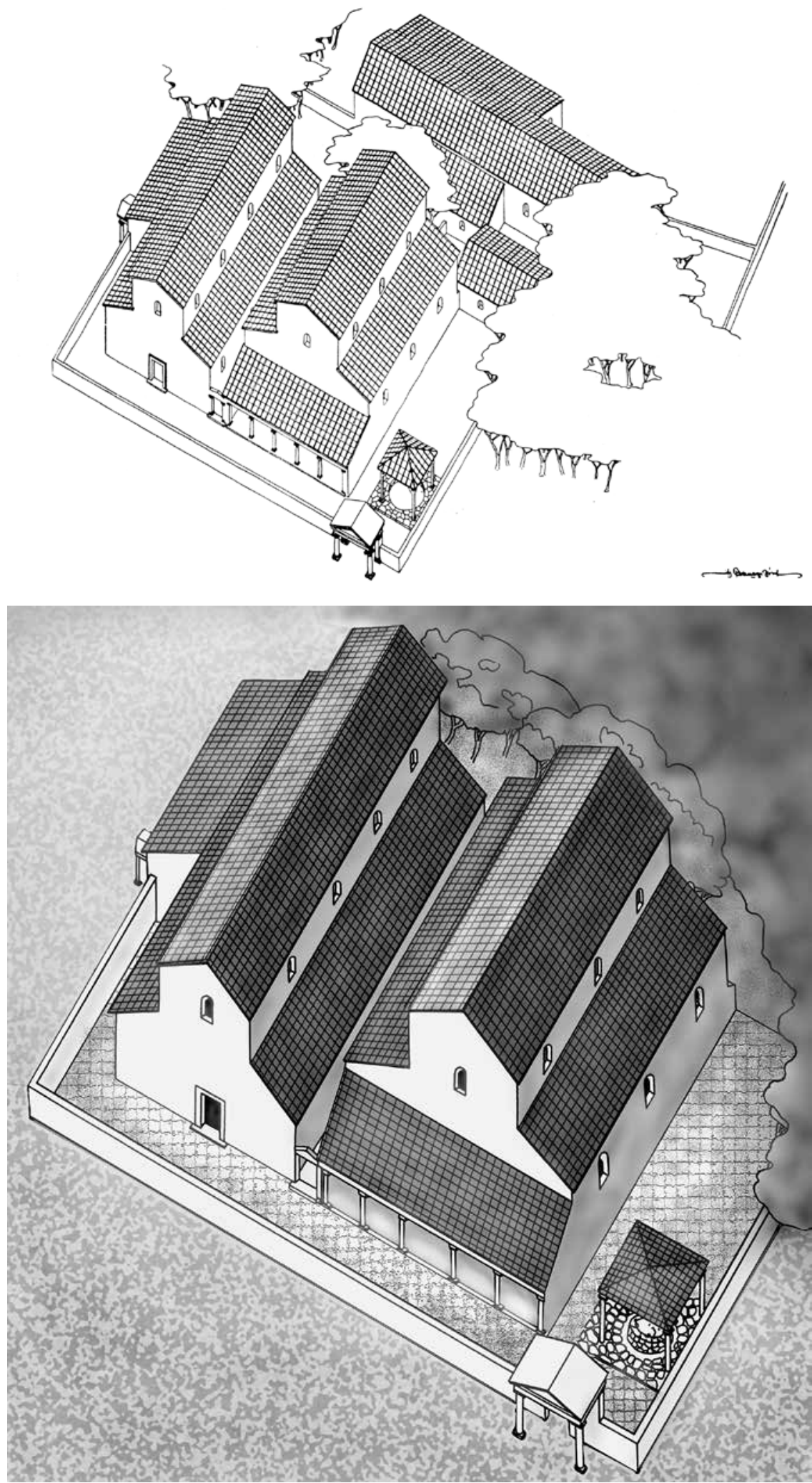

Fig. 7. Reconstruction of the so-called Double Basilica by L. Nagy and Gy. Hajnóczi (after Póczy 2004, 337, fig. 122) Acta Archaeologica Academiae Scientiarum Hungaricae 69, 2018 


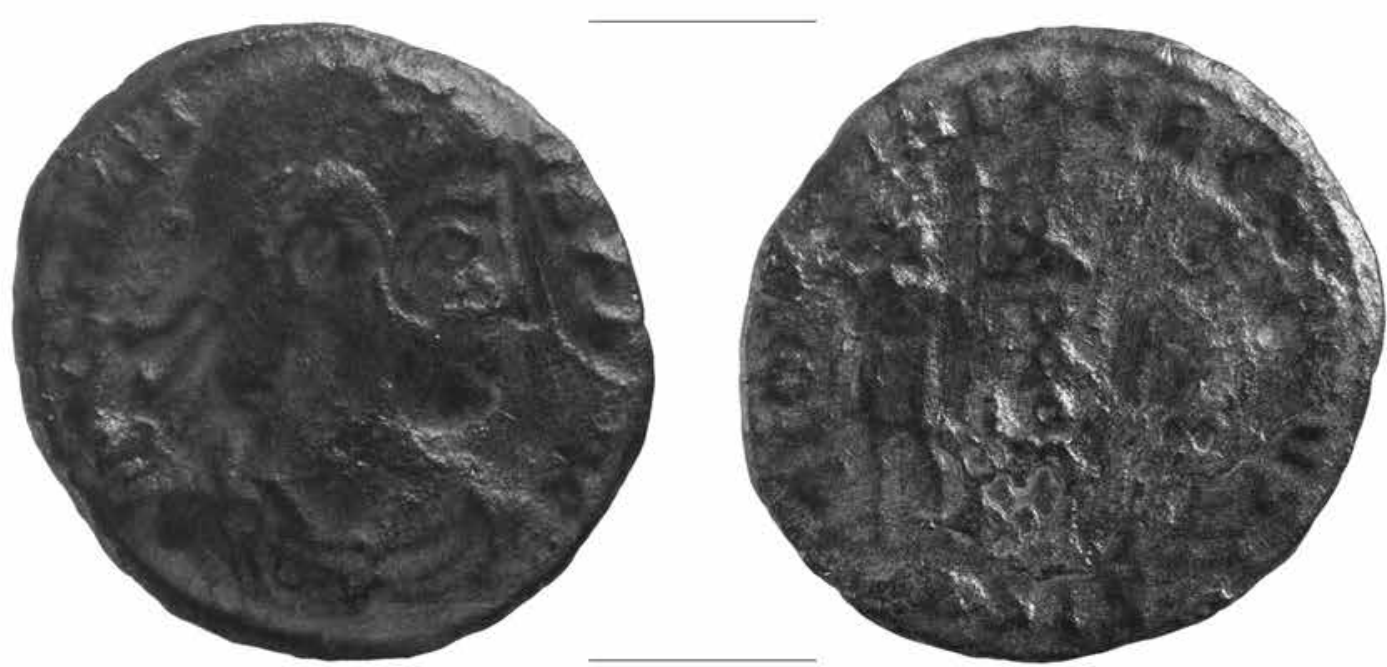

0

$1 \mathrm{~cm}$

Fig. 8. Coin of Constantius II found in the half-filled foss $a$ of the southern town wall (Photo: P. Komjáthy)

P. Zsidi describes the abandonment of the Civil Town as being either the result of a single step or as a gradual process and dates the final abandonment to the turn of the fourth-fifth century AD. ${ }^{55} \mathrm{P}$. Zsidi also believes that the Danube bank remained in use until the fifth century AD at which time the watchtower and the nearby Christian buildings would still have been in use. ${ }^{56}$ In any case, she also blames the early (nineteenth century) excavations for destroying the latest layers and features in the eastern part of the town resulting in such sporadic data for the fifthsixth century exploitation of the area. ${ }^{57}$

Margit Nagy, a researcher dealing with the Migration Period of Óbuda, noted that the number of the romanized population must have decreased by the turn of the fourth-fifth century in the settlement complex of Aquincum and also mentions that most of the cemeteries of both the Civil and the Military Town only remained in use until the end of the fourth century. She also mentions the "famous" cicada brooch found north of the Symphorus Mithraeum (see p.147) as the only well documented piece of evidence reflecting a Late Roman presence in the settlement. ${ }^{58}$

\section{THE END OF LIFE IN THE TOWN - RECENT EXCAVATION RESULTS}

As seen above, until the end of the twentieth century, several attempts were made to describe the latest period(s) of the Civil Town. ${ }^{59}$ Nevertheless, the problem is still not resolved since excavations carried out in the settlement over the last 10 years and revalutions of old excavation documentations have shed some new light on the issue. (Fig. 9)

In the following section, some case studies will be described - in topographical order from North to South, West to East. With these studies a somewhat different picture emerges concerning the latest occupation phase of the antique town. Revaluating old excavation doumentation (diaries, drawings and photographs), finds and new data from control excavations in the North-Eastern zone of the Civil Town (fully built-in with strip buildings) has recently clarified understanding of this industrial-commercial quarter of the settlement, revealing at least eight con-

\footnotetext{
${ }^{55}$ ZsIDI 2002a, 121-122.

${ }^{56}$ ZSIDI 1997-1998, 589.

${ }^{57}$ PócZY-Zsidi 2003, 65.
}

${ }^{58}$ NAGY 1993, 353-354.
${ }^{59}$ More recently: GRAMMER 2015, 11-70. 




Fig. 9. Plan of the Civil Town with locations of recent research (Drawing: K. Kolozsvári)

struction phases dated between the last quarter of the first century to the end of the third century (of which Phase 7 and 8 are relevant here) ${ }^{60}$. Wings of Building no. I (previosuly thought to be the basilica) were excavated several times between 1882 and 1993. ${ }^{61}$ (Fig. 9/1) Based on this revaluation work, the united western and central wings may actually have functioned as a collegium building from the end of the second-beginning of the third century onwards (from Phase 5) and well into the third century, while the eastern wing was a dwelling house with workshop. ${ }^{62}$ The latest datable finds from this area are a coin of Gordian III and - most probably - an imperial statue head, dated to the middle of the third century. ${ }^{63}$ The latest period that could be observed here (Phase 8 ), dates to the end of the third century and saw the construction of a street/road in the North of the complex, while the eastern wing of the structure retained its dwelling function. (Fig. 10)

Another strip building from this part of the Civil Town, Building no. XXIX, the so-called Glue Manufacturing workshop (and tannery) was also excavated several times from the nineteenth century onwards. Control excavations have been on-going here since $2004 .{ }^{64}$ (Fig. 9/2) The tanning workshop was still active during latest phase (Phase 8 ) in the southern part of the building (though at a reduced scale) with newly created small rooms on the eastern side - possibly shops - opening towards the neighbouring Third Bath (probably taking advantage of the pedestrian traffic here). (Fig. 11) Rooms in the northern, dwelling area were also renovated: the floors and the hypocaustum system were renewed. ${ }^{65}$ Based on the associated finds, this phase dates to the middle/second half of the third century. ${ }^{66}$ No later phases could be observed in this building either, even though three small, glass beaker fragments could be dated

\footnotetext{
${ }^{60}$ LÁNG 2012a.

${ }^{61}$ See prev. footnote and its summary: GRAMMER 2015, 43.

${ }^{62}$ On the periodization and function of the western and central wings: LÁNG 2013, 106-113.

${ }^{63}$ LÁNG 2013, 106, 112.
}

${ }^{64}$ LÁNG 2016a, 363-371 with further bibliography; latest report on this work: LÁNG 2016b, 47-59.

${ }^{65}$ See previous footnote.

${ }^{66}$ LÁNG 2008, 277-278. Generally, Phase 7 in building no. XXIX is identical with Phase 8 in the northeastern zone. 

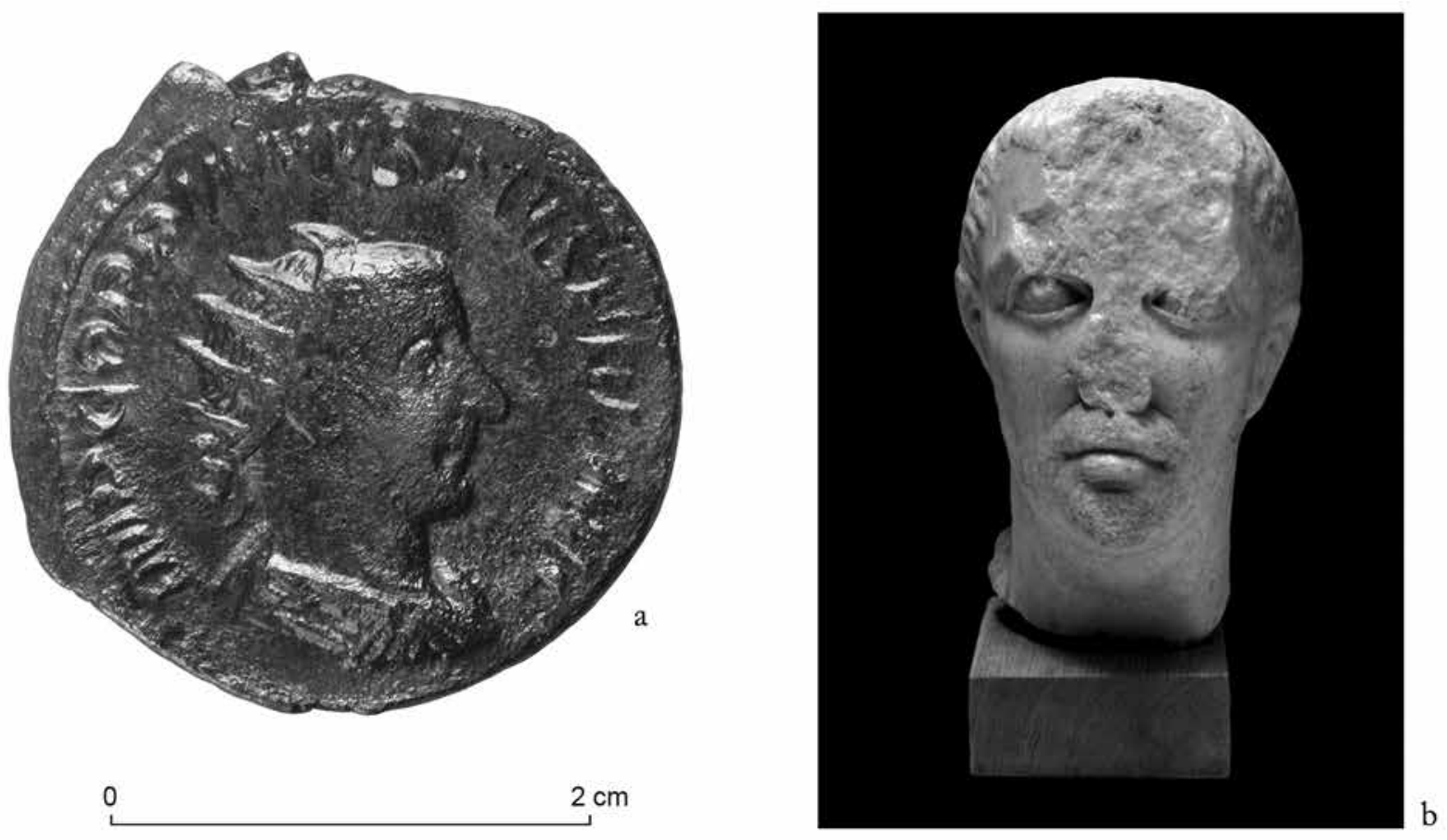

Fig. 10. Coin of Gordian III and statue head from Building no. I (Photo: P. Komjáthy)
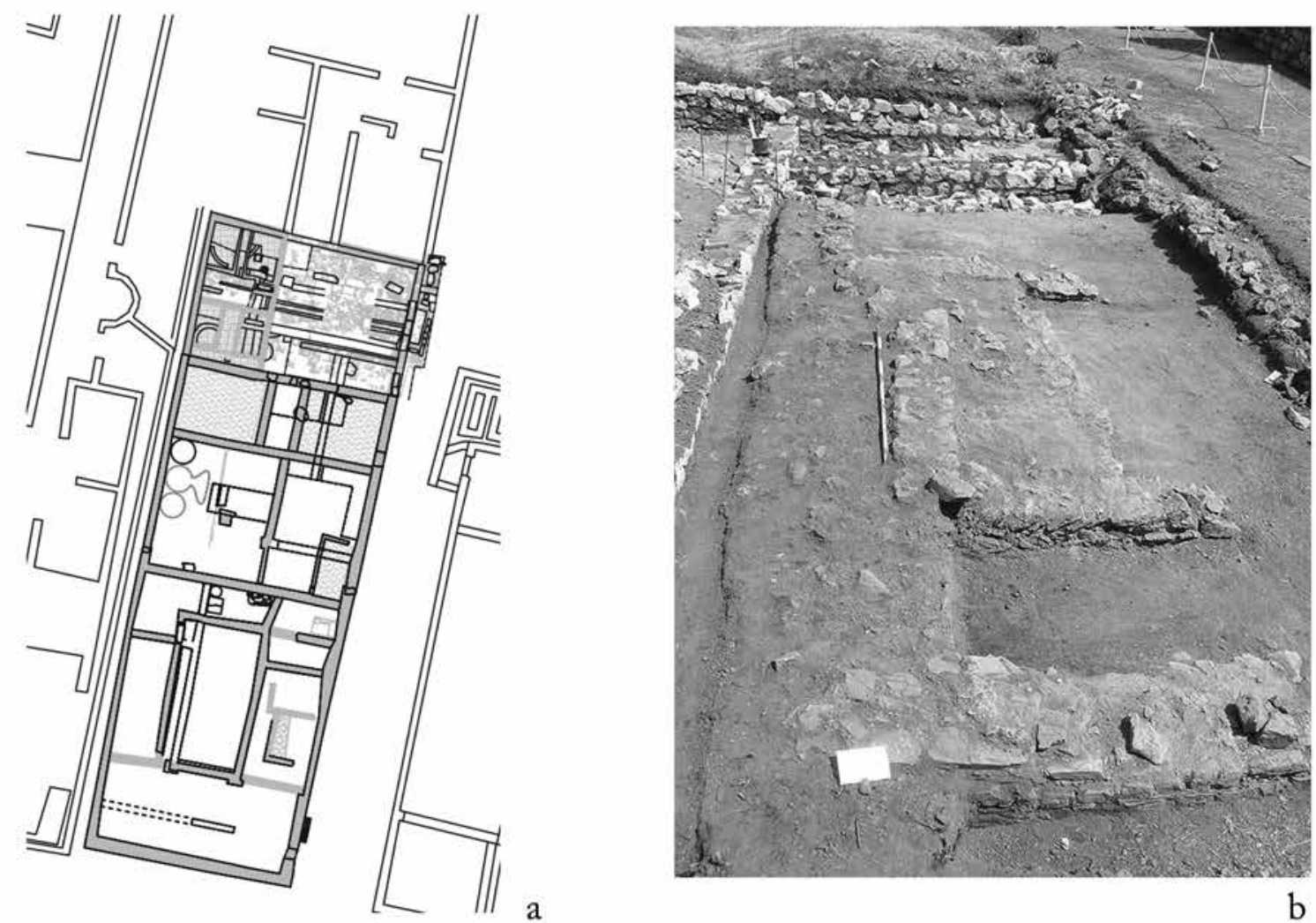

Fig. 11. Phase 8 in Building no. XXIX and excavation photo of the late Roman rooms (Photo and drawing: O. Láng) 
to the fourth century. Nevertheless, since these were stray finds from earlier excavation depots and the uppermost layer, they can not be used as reliable dating evidence.$^{67}$ Anyhow, since this building is located along the main WestEast road, the presence of late finds would not be surprising. ${ }^{68}$ The building complex of the tholos-type macellum - itself a unique building type in the Western Roman provinces ${ }^{69}$ - is located along the main North-South road, in the settlement core where several other public buildings (e.g. the Great Bath and the Sanctuary of Fortuna Augusta) can also be found. (Fig. 9/3) It has been excavated several times since the end of the ninteenth century. ${ }^{70}$ As a result, the topmost layers and features could only be partially observed. The recent revaluation of the excavation documentation and finds enabled the identification of seven construction phases in the building of which Phase 6 reflects the latest Roman Period use of the macellum, while Phase 7 already represents a modern period disturbance at the site. ${ }^{71}$ According to the evaluation of the diaries, drawings, photos and finds, the latest phase is characterized by small-scale renovations and additions in the western part of the building, along the western façade, opening to the North-South main road. (Fig. 12) These features include an apse-like room with a pavement and short segments of collapsed, thin walls, all of rather poor-quality construction. No similar features were observed elsewhere in the building. Even though no coherent plan can be drawn of these constructions, they still indicate the continued use of this part of the market building. There are few finds related to this phase. However, based on the relative stratigraphical layout of this phase's features, analogous features and finds from the northeastern and southern zones of the settlement, the last Roman period of the macellum could be dated between the end of the third-beginning of the fourth century AD. ${ }^{72}$

The central part of the so-called "Painter's House", in the southern part of the settlement, was first excavated by T. Nagy in 1941, while it was re-excavated and the northen part freshly unearthed by the author of this article between 2009-2011. ${ }^{73}$ (Fig. 9/4) The strip building with its central corridor, rooms decorated with vivid frescoes, an additional cellar and a possible backyard underwent four construction phases possibly starting from the first half of the second century AD and finding its final form around the turn of the second-third century. The last phase is characterized by some renovations in the building: reconstruction of a room with floor heating, new terrazzo pavement and a small, new water conduit made of ceramic piping that cut through the northern façade of the house. (Fig. 13) The dating of the phase is based partially on a mint-condition coin of Salonina from the foundation of the latest terrazzo pavement and a middle of the third century coin found in the roof debris - practically on the presentday surface - of the neighbouring strip building, East of the "Painter's House". ${ }^{74}$ Terra sigillata finds from both buildings further attest this dating: fragments of Rheinzabern, Westerndorf and possibly a few Pfaffenhofen sherds were discovered in the latest layers ${ }^{75}$ of the northern section of the "Painter's House", all dating to the first half of the third century at the latest. ${ }^{76}$ Finds from the same worskhops occured in the latest layers of the strip building lying to the East of the "Painter's House" as well. ${ }^{77}$ These datable finds correlate well with those finds (mainly also terra sigillata) found by T. Nagy in 1941, confirming that the building may have been abandoned (?) around the second half-end of the third century. ${ }^{78}$

Still in the southern zone of the settlement, the control-excavation at the so-called "deversorium", just outside the southern town wall and gate, also revealed new data about the last construction phase of this building. (Fig. 9/5) The building-complex that was first excavated by T. Nagy in 1946-47, was identified as a deversorium with a courtyard, rooms and kitchen. ${ }^{79}$ Unfortunately, no documentation survives from this excavation, and thus, no

${ }^{67}$ KeLEMEN 2017.

${ }^{68}$ The road probably also remained in use following the Roman occupation (no wonder that the modern railway line Budapest-Esztergom follows the same path) just as the main North-South road, see below.

${ }^{69}$ LÁNG 2003, 176-199. and Fig 8.

${ }^{70}$ For the complete publication of the macellum: LÁNGNAGY-VÁMOS 2014

${ }^{71}$ LÁNG-NAGY-VÁMOS 2014, 77-87.

${ }^{72}$ Op. cit. 86-87. Previously, before the whole find material was revised, I also considered this phase to be a purely fourth century phase, based on K. Póczy's observations. This was most probably wrong: LÁNG 2003, 174.

${ }^{73}$ NAGY 1958, 149-189; LÁNG 2011a, 32-44. For the latest reports on the excavations: LÁNG 2010, 188-190; LÁNG 2011b, 18-35; LÁNG 2012b, 17-36.

Acta Archaeologica Academiae Scientiarum Hungaricae 69, 2018
${ }^{74}$ LÁNG 2012b, 27, 31.

${ }^{75}$ Roof debris: SU 346; Layers SU 256, 258, 326, 382; Pavement SU 442 .

${ }^{76}$ Unpublished report. Analyses of the terra sigillata find material was carried out by P. Vámos. I am grateful for his help.

${ }^{77}$ Layers: SU 244, 245, 246, 253, 257, 280, 290, 317. See also: previous footnote.

${ }^{78}$ NAGY 1958, 153; LÁNG 2012b, 28. Even though recent excavations revealed no trace of destruction or fire, in the southern part of the building, T. Nagy found secondarily burnt terra sigillata and fresco fargments. Based on these finds, he suspected that the house was destroyed by fire: NAGY 1958, footnote 36 .

${ }^{79}$ NAGY 1948, 121-122. 

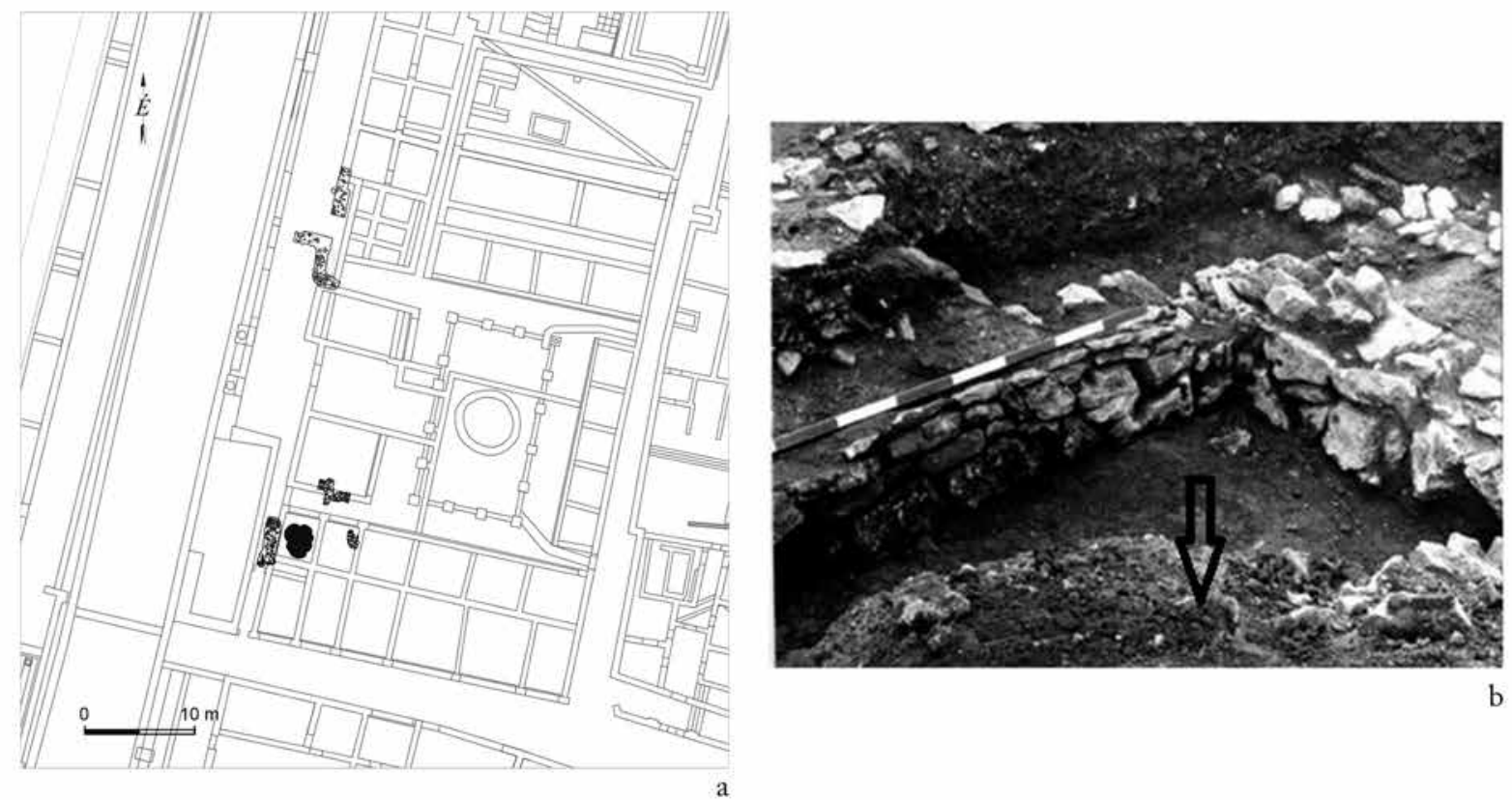

Fig. 12. Phase 6 in the macellum and excavation photo of late feature in the western part of the building (Drawing: O. Láng, Photo: BHM Aquincum Museum)
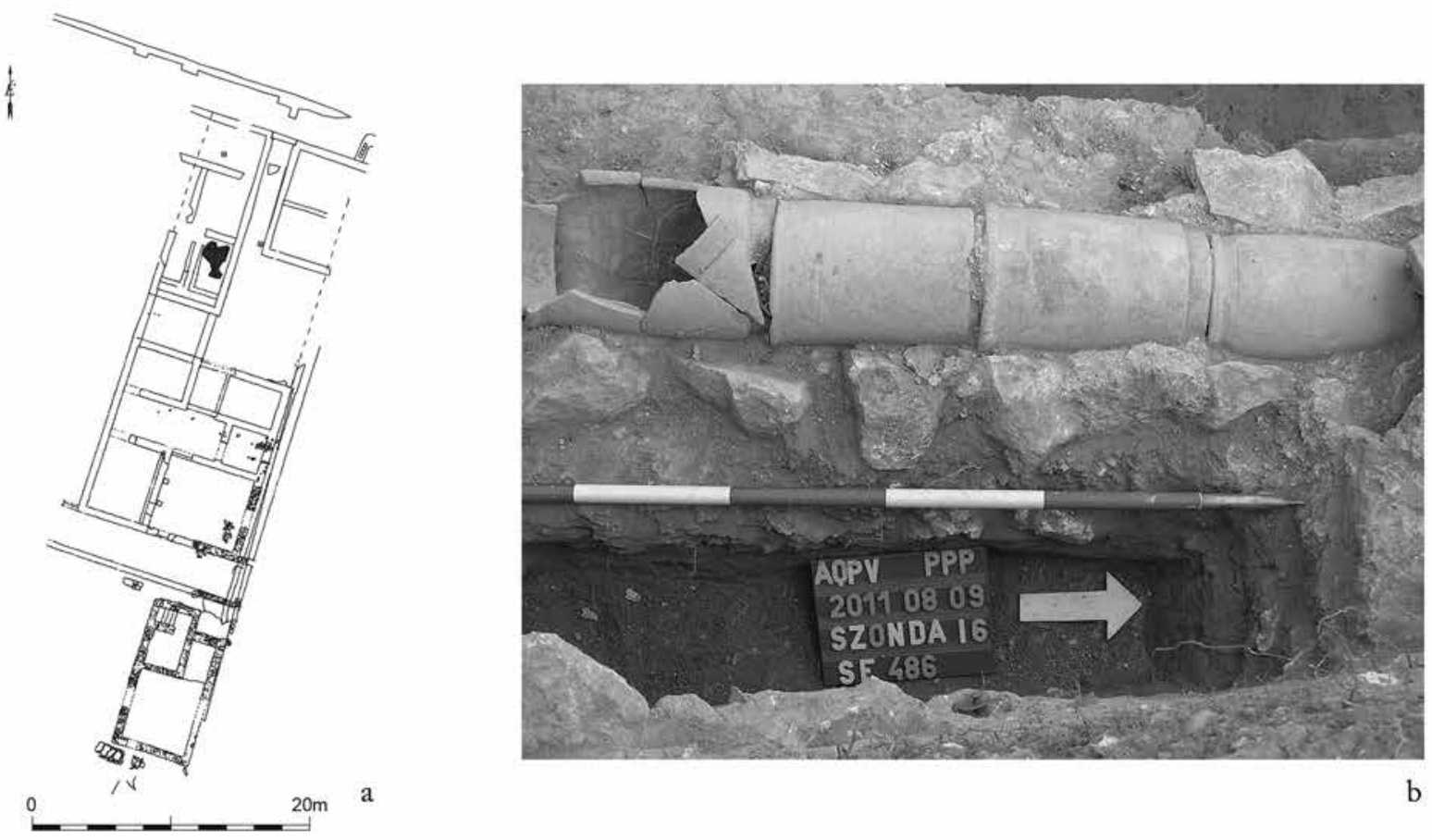

Fig. 13. Last phase of the "Painter's House" and the late Roman water conduit (Drawing and photo: O. Láng) 


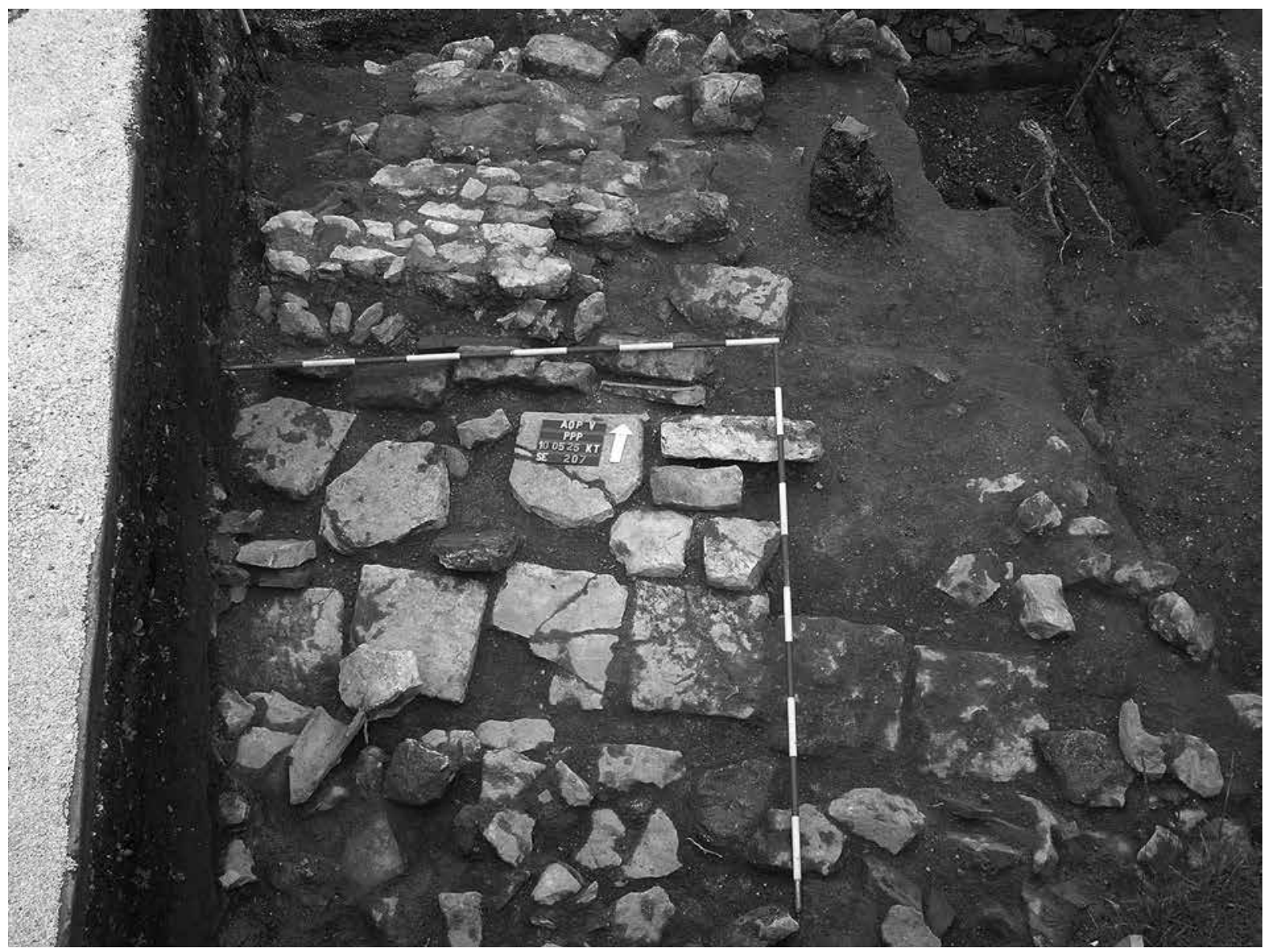

Fig. 14. Fallen segment of the southern town wall (Photo: O. Láng)

data remained of the last occupation phase at the complex. Geophysical survey carried out in 2010 revealed further walls in this area indicating the presence of more East-West oriented strip buildings (rather than a single building) ${ }^{80}$ Even though control excavation by the north-western corner of the supposed "deversorium" provided no further information on either the ground plan or the function of the building(s), it shed some light on its last occupation phase. Based on observations, the building - possibly built later than T. Nagy suspected, namely around the turn of the second-third century - was extended to the North sometime around the middle of the third century(?) with a wall that was built over the, by that time already filled, fossa belonging to the southern town wall. We could not get any further information on any later phases, nor were any fourth century finds found in this area. Research on segments of the southern town wall - just next to the so-called "deversorium" - showed the wall to have been partially robbed although elsewhere its foundation survived ( $2.2 \mathrm{~m}$ wide). To the East, a $3 \mathrm{~m}$ "high" wall segment (comprised of large monolith stone blocks as well as smaller stones alternating with rows of brick) was also observed, fallen over the already filled fossa. (Fig. 14) Concerning the dating of the southern town fortifications, the middle of third century "deversorium"-wall built over the fossa (see above) provides a terminus ante quem for the filling of the ditch with a coin of Antoninus Pius, found in the levelling layer of the internal rampart along the wall, also provides data to the elimination of the fortification here. The relative chronology of the site showed that the town wall was already falling apart and its fossa filled in Roman times, while the top of the surviving wall was reused for a pavement (or street?). ${ }^{81}$ To sum up: no information on the late use of the fortifications could be demonstrated.

The western part of the Civil Town has only been partially excavated and there are still high hopes that the fourth century phase at the settlement will be found there. Parts of a richly decorated building was discovered

${ }^{80}$ LÁNG 2011b, 19-20.

${ }^{81}$ Op. cit. $23-24$. 


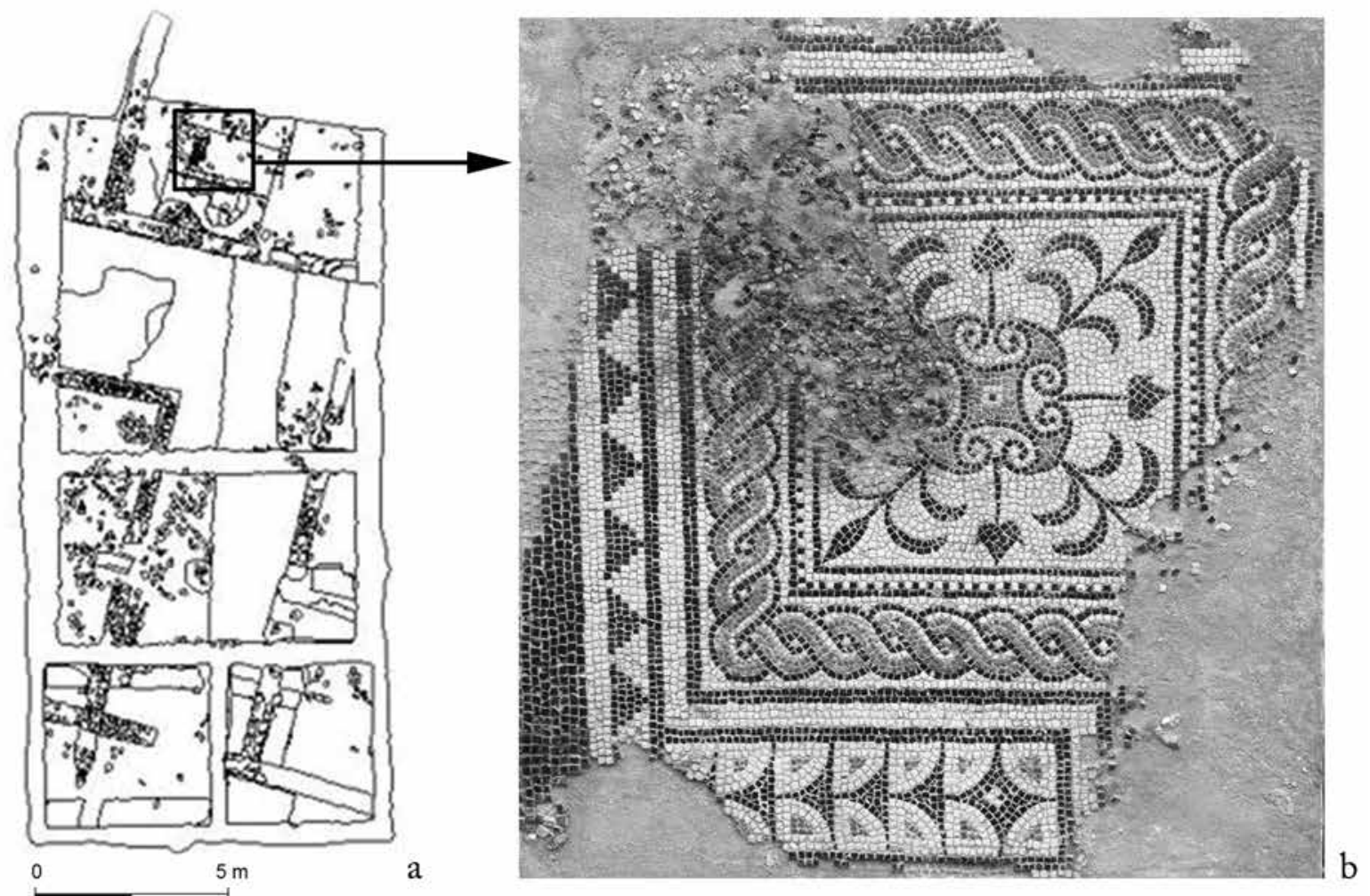

Fig. 15. Plan of the richly decorated building and photo of the mosaic floor (Drawing: Piline Ltd., Photo: P. Komjáthy)

close to the forum area and the main East-West road, in the northen part of this zone as the result of preventive excavations in 2008. ${ }^{82}$ (Fig. 9/6) Though, no complete ground-plan could be reconstructed, four construction phases could be identified. The building - which is possibly a big one - had floor heating installed and was decorated with wall paintings and stucco around the beginning to middle of the third century (Phase 3). (Fig. 15) Its main room was paved with a mosaic with floral and geometric motifs and complemented with white marble slabs alternating with red marble stripes by its entrance. The function of the building is still uncertain: it could either have been a public building (as it lies close to the forum) or a bath building (layers of limescale in one of the heated rooms suggest the presence of standing water). The structure may also have served as a private house as well. The last (fourth) occupation phase observed here saw minor changes, namely an East-West running stone chanel and a stone trough that cut across the walls. The function as well as the starting and end points of these features are unknown. Further construction phases from the middle of third century could already be observed here as well: Roman walls and pavements appeared below the modern filling layer (deposited here in the 1970s). Two, third century coins together with a coin from 1816 as well as fragments of glazed mortaria (which is not necessarily later than the third century ${ }^{83}$ ) were discovered in a large pit cutting through the latest walls and layer. These finds possibly indicate that no further Roman construction phase existed here. ${ }^{84}$ No securely dated fourth century finds or features could be observed in this area.

North-South oriented strip buildings lined both sides of the main East-West road leaving the town's western gate and, thus, already lying outside the town wall. (Fig. 9/7) The first excavations were carried out here by K. Póczy, who managed to identify houses with porticos opening to the road as well as the workshops and shops sitting behind

\footnotetext{
${ }^{82}$ LÁNG 2009a, 17-28; LÁNG-LASSÁNYI 2015, 19-23.

${ }^{83}$ Glazed mortaria fragments could be connected to the period before $\mathrm{AD} 230$ at Salla. No finds of this type could be securely
}

connected to fourth century layers. VARGA 2010, 166, footnote 17 (with further evidence on third century dating).

${ }^{84}$ On the last 2 phases: LÁNG 2009a, 19-27; LÁNGLASSÁNYI 2015, 22 


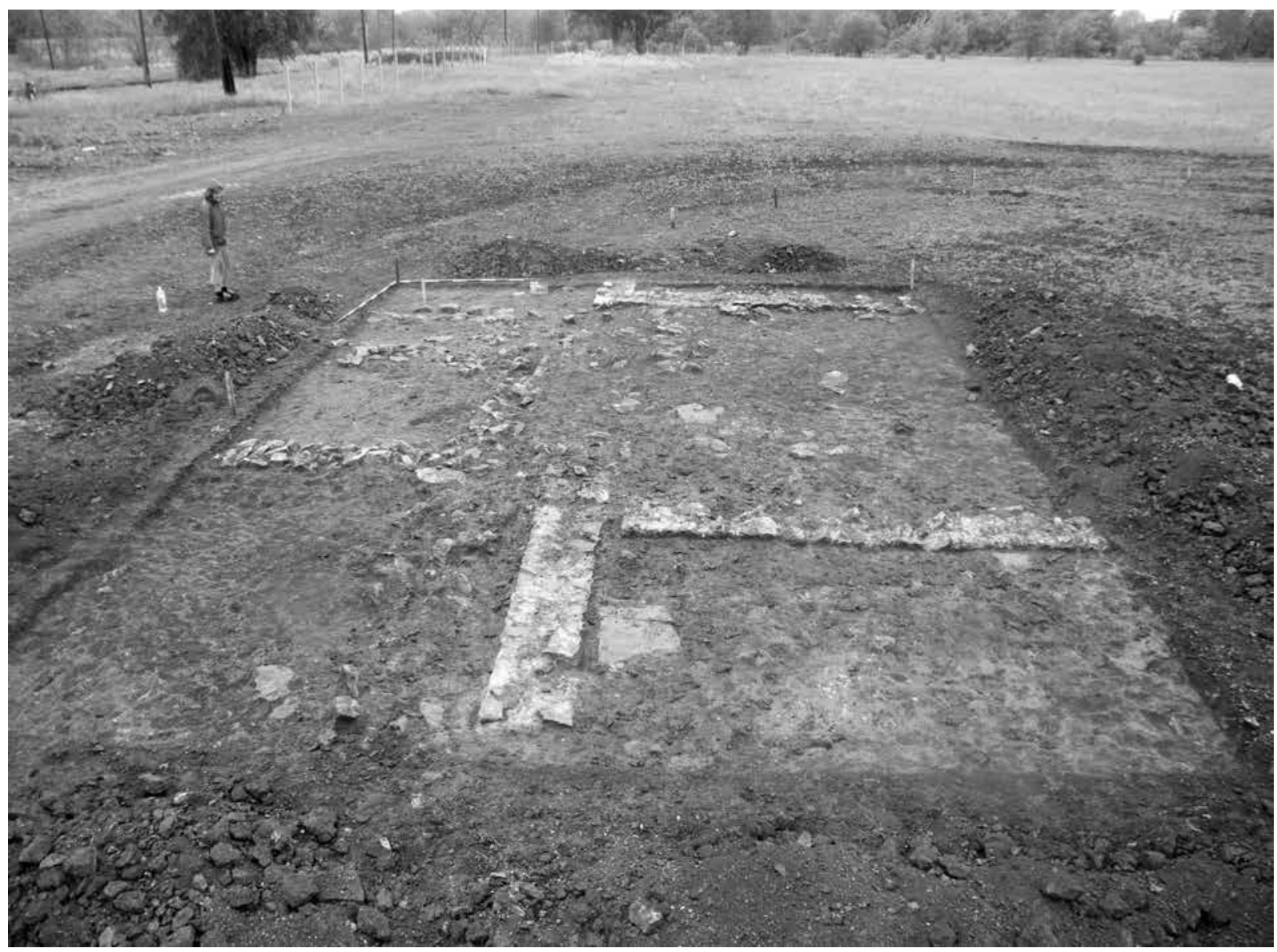

Fig. 16. Excavation photo of a strip building lying along the main East-West road (Photo: G. Lassányi)

it (ovens, millstones, storage jar etc.). ${ }^{85}$ She could also distinguish two construction phases here of which the later was dated to the beginning of the third century. ${ }^{86}$ Two cremation burials and a walled "tomb chamber" were dug into the remains of the strip buildings. ${ }^{87}$ The latter - based on graves with similar structures excavated in the eastern and southern cemeteries of the Civil Town - could be dated to the second half of the third and the turn of the third-fourth century. Thus, this area was already serving as a roadside cemetery after the houses were abandoned in this period. ${ }^{88}$ The northern and central part of another strip building was researched briefly by G. Lassányi here in 2012. (Fig. 16) Based on his observations, the house could have burned down sometime after the middle of the third century. No later rebuilding could be observed. ${ }^{89}$ Further remains of this row of strip buildings as well as a segment of a road running North-South were discovered in 2013. Here, the latest datable phase fell into the second-third century AD..$^{90}$ The latest feature observed in this zone was a single inhumation grave (similarly to the one found by K. Póczy - see above), dug into the area of the by that time already abandoned strip building. (Fig. 17) Possibly a mother and her daughter were buried in the brick grave, where - apart from other grave goods and personal objects - a coin, possibly dated to the third century was also discovered. Based on the finds, the grave can be conditionally dated to the second half of the third-early fourth century. ${ }^{91}$ Further information on the late history of this zone was provided by a metal

${ }^{85}$ Summarized in: GroH et al. 2014, 370.

${ }^{86}$ Based on her excavation documentation: BHM - AA

$177-77$.

${ }^{87}$ PÓcZY 1976, 33.

${ }^{88}$ LASSÁNYI 2013, 30.

${ }^{89}$ Mainly based on the large number of coins dating from the age of the Barracks Emperors: LASSÁNYI 2013, 29.

${ }^{90}$ LÁNG-LASSÁNYI 2014, 21-22.
${ }^{91}$ LÁNG-LASSÁNYI 2015, 28-29. Further Late Roman graves connected to the town or its immediate vicinity were discovered in the North-Eastern part of the town, cutting earlier buildings and South of the Southern town wall, also cutting earlier building remains: PeTŐ 1976, 32 and Petỏ 1984, 276. For further information on Late Roman graves in the neighbouring cemeteries see: LASSÁNYIVASS $2015,169-172$ and see footnotes 92-93. 


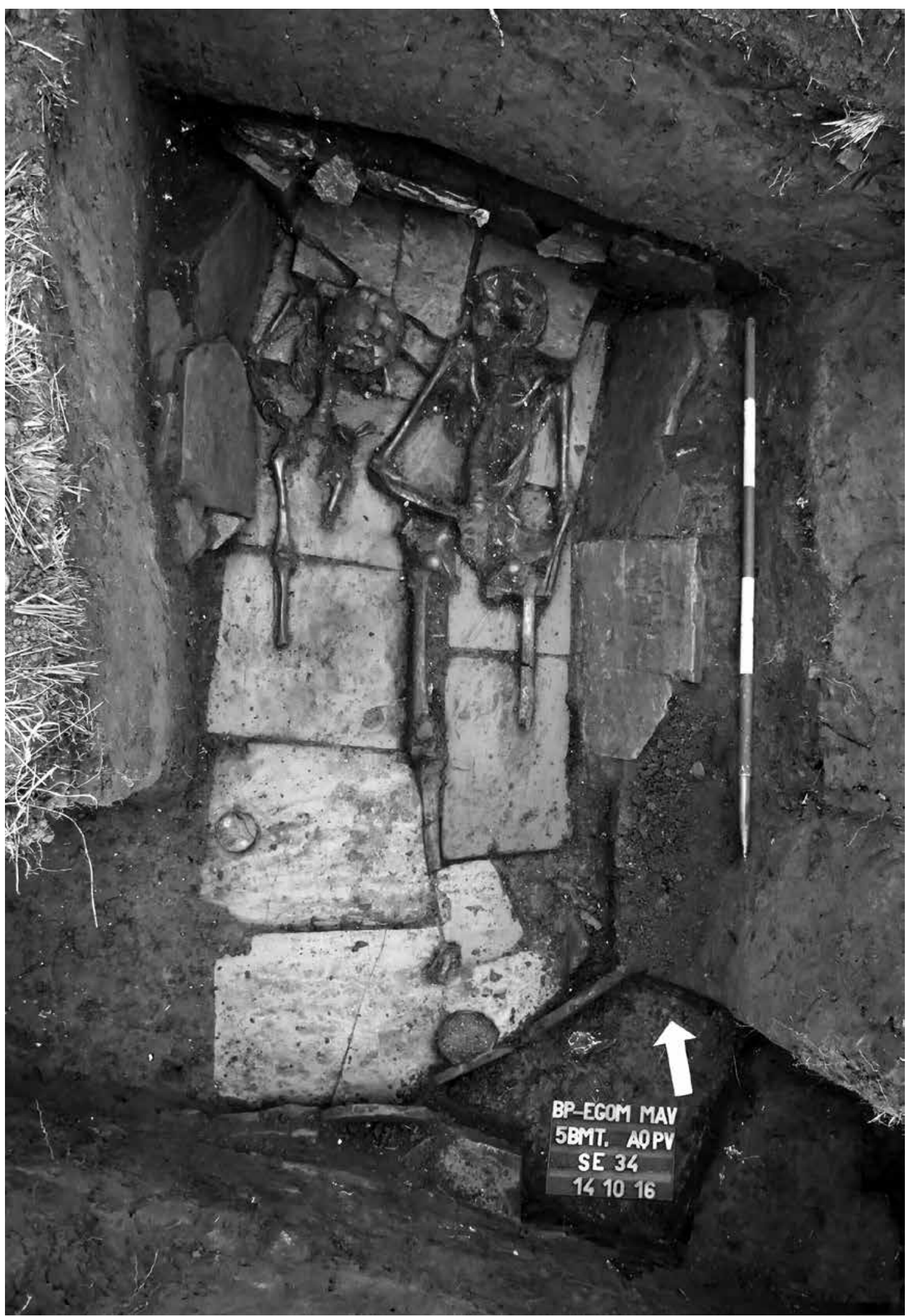

Fig. 17. Double burial outside the Western town gate, in the zone of the strip buildings (Photo: G. Gyenes) 
detecting survey that was carried out West of the town wall that resulted in the discovery of more than 300 metal finds in $2012 .{ }^{92} \mathrm{~A}$ total of 63 Roman coins were found, of which only seven (!) could be dated to the fourth century. ${ }^{93}$ Their presence can be connected to the main East-West road that must have remained in use long after the abandonment of the settlement (see above). The find material, thus, does not not support the theory of a fourth century phase in this zone. ${ }^{94}$ Summing up the history of what we now know of the western foreground of the Civil Town: even though the main East-West road may still have been used, buildings were probably abandoned by the end of the third century.

The so-called "dark-earth" phenomenon, a layer that is usually connected to the abandonment of Roman settlements in many European as well as some Pannonian sites ${ }^{95}$ is hard to observe in the eastern part of the Aquincum Civil Town due to the numerous excavations that took place there from the nineteenth century onwards. Such a layer was first observed West of the Western gate of the town - an area undisturbed by earlier research - on top of the latest (third century) Roman layers, indicating the abandonment of the settlement there. (Fig. 18) Only modern fill could be documented above this dark layer. ${ }^{96}$

Further, representative data could be gleaned on the latest phase of the settlement as the result of a systematic metal detecting survey carried out in the western part (thus, a mainly undisturbed area, see above) of the town between 2014 and 2015. (Fig. 9/8) This survey was carried out in the South-Western part of the Civil Town. Altogether 200 metal finds were discovered. ${ }^{97}$ During this campaign, 68 coins were also found of which only seven (!) could be dated after the third century (between AD 310 and 578).$^{98}$ These latter coins were found scattered about the area. ${ }^{99}$ In sum, the significantly small number of fourth century coins (and other finds) found in a previously only partially - or mostly not at all - researched area, brings into question whether fourth century phase existed in this part of the town. ${ }^{100}$

Consideration of Late Roman coins from the eastern part of the settlement, a recent revision of the Numismatic Collection of the Aquincum Museum showed that out of the several hundred coins whose find locations can be securely identified (namely the Civil Town), only 29 (!) can be dated to the fourth century. ${ }^{101}$ (Fig. 19) Most of them were found closer to the eastern edge of the settlement (nine coins, mostly with uncertian find locations ${ }^{102}$ ), while a significant number were discovered along or in the vicinity of the two main roads (seven coins ${ }^{103}$ ). Five coins $^{104}$ were associated with the so-called Symphorus Mithraeum and its immediate vicinity ("Painter's House") while a further seven coins ${ }^{105}$ lack any definite find spot at all. One fourth century coin was found East of the Great

${ }^{92}$ Including brooches, keys, furniture ornaments and casket fittings and even a small spearhead. See following footnote.

${ }^{93}$ LASSÁNYI 2013, 22.

${ }^{94}$ Op. cit. 29. See also: p. 6. Furthermore, the continuous use of the main North-South road is attested by Migration Period potsherds found on the surface of the road, close to the Civil Town: ZsIDI 1997-1998, 588. A similar situation could be observed along the limes road, North of the auxiliary camp of Campona, where fourth century coins were brought to light in a cemetery belonging to as yet an unknown indigenous vicus, although the cemetery itself was used between the middle of the first and the first third of the second century AD. The late coins most probably are connected to the use of the road: BESZÉDES-SZILAS 2007, 246-247.

${ }^{95}$ Bíró-TOMKA 2013, 521-532.

${ }^{96}$ LÁNG-LASSÁNYI 2015, 30.

${ }^{97}$ Again, mainly brooches, belt fittings, earrings, furniture ornaments, lead votive objects and even a fragment of a military diploma. None of them dates after the third century. See the following footnote.

${ }^{98}$ LASSÁNYI-ZSIDI 2014, 127-128; LASSÁNYI-ZSIDI 2015, 39-49. A small trial trench was also opened in this zone, where the latest - topmost - layer could be dated to the third century.

${ }^{99}$ Pers. comm. G. Lassányi. Two further fourth century coins derive from the area of the main North-South road, found during earlier excavations: 69.1.50: very worn Late Roman, fourth century coin /can not be identified more precisely/; 98.60.327: Late Roman, fourth century coin /can not be identified more precisely/.

${ }^{100}$ Planned excavations (in the framework of the so-called “Interstudex” program) carried out here by K. Póczy and Gy. Hajnóczi between 1966-1972 revealed four construction phases. According to the excavators, the latest phase could be dated to the beginning of the fourth century but was already destroyed by by deep plowing: PócZYHAJNÓCZI 1968, 22-23.

${ }^{101}$ Revision was carried out by B. Rikker, keeper of the Numismatic Collection of the Aquincum Museum. I am grateful to him for his help!

10233512 (inv.no.): Valentinianus I; 70064: Valens; 70073/ a-b: both coins of Iovianus; 57.26.1: AE3, Valentinianus I; 57.26.2: AE3, Constantius II; 57.26.4: AE3, Valens; 57.38.1: AE3, Valentinianus I; 57.47.1: AE3, Valentinianus I.

${ }^{103}$ R525/87: AE3, fourth century; 40/3: AE4, Constantius II; 38/3: AE3, Iulianus Apostata; 36/5: AE3, Late Roman; 98.49.3867: Late Roman, fourth century coin (can not be identified more precisely); 98.60.327: AE2; fourth century 98.49.3867:AE3, possibly third-fourth century.

${ }^{104}$ 56.200.125: follis AE3, Constantinus I; 56.200.128: follis AE3, Constantinus I; 56.200.130: follis AE3, Constantinus I;56.201.50: 2 Late Roman, fourth century coins (can not be identified more precisely).

${ }^{105}$ R2046: Late Roman, fourth century coin (can not be identified more precisely); R2048: Late Roman, fourth century coin (can not be identified more precisely). 70034: Valens; 70088: Constantius Gallus; 56.154.10: Late Roman, fourth century coin (can not be determined more precisely); 56.154.11: Late Roman, fourth century coin (can not be identified more precisely); 76.4.20: Late Roman, fourth century coin (can not be identified more precisely). 


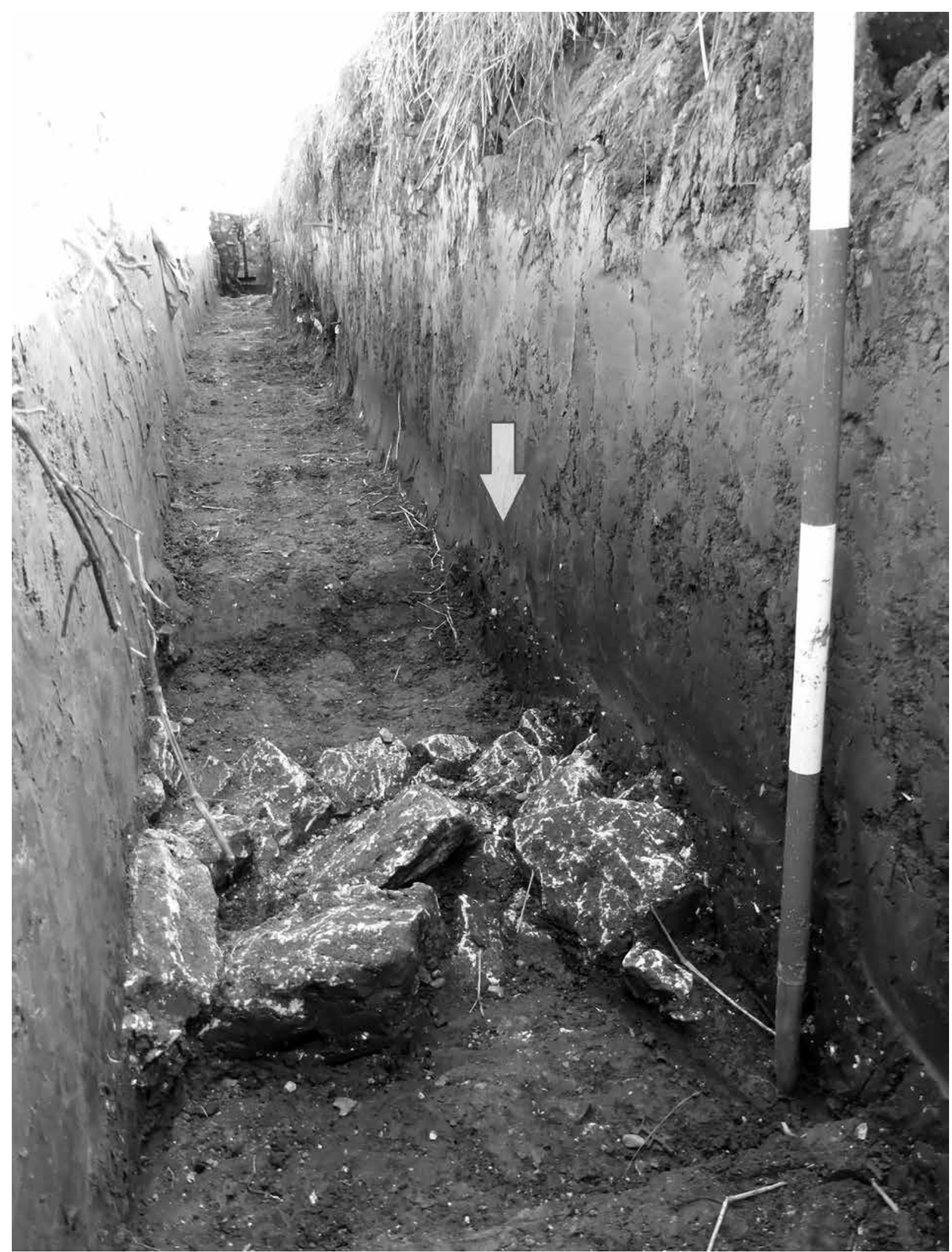

Fig. 18. "Dark-earth" observed in the Western part of the Civil Town (Photo: O. Láng) 


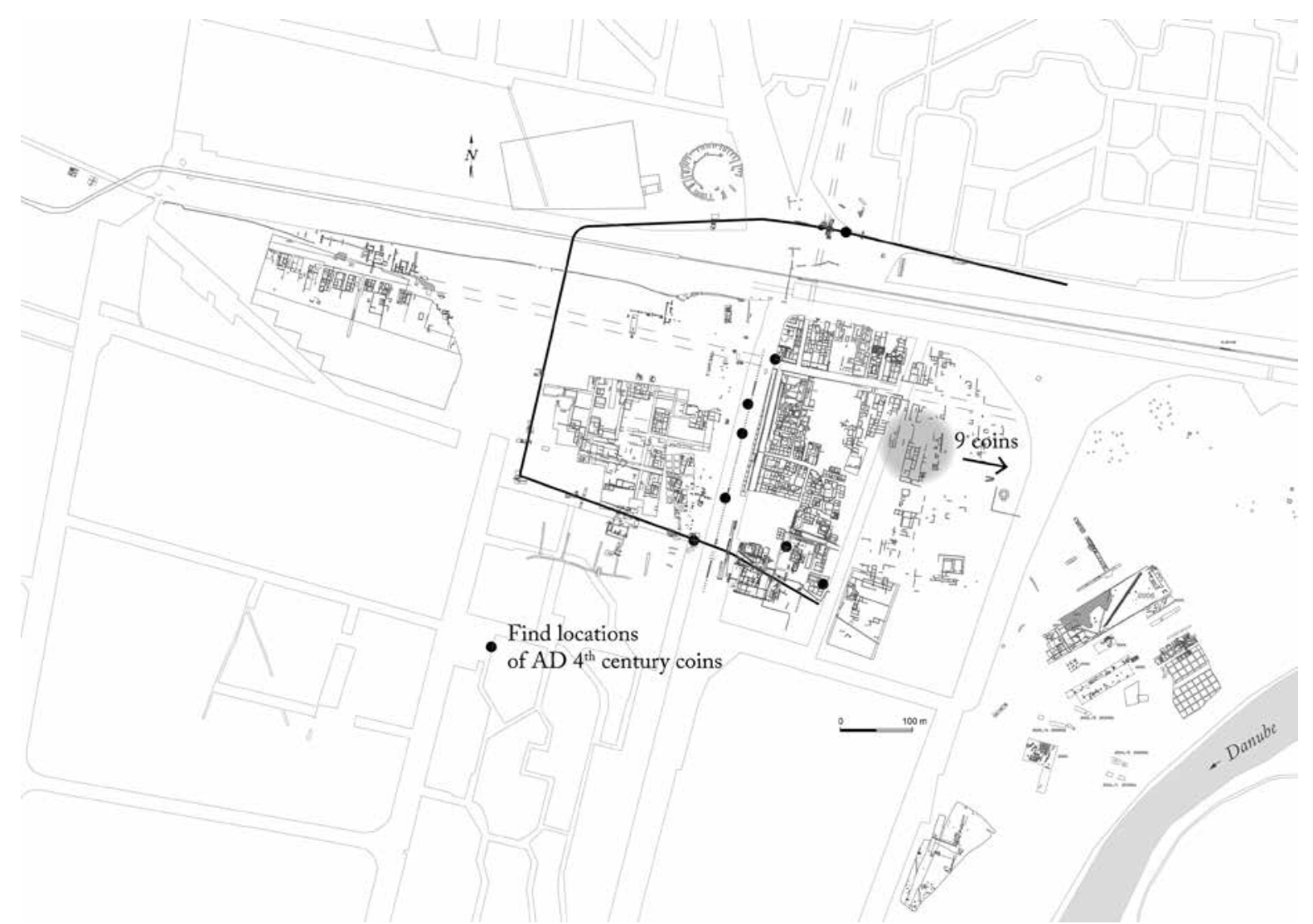

Fig. 19. Find locations of fourth century coins in the Eastern part of the Civil Town (Drawing: K. Kolozsvári)

Bath (by the old museum building). ${ }^{106}$ Thus, the spread of fourth century coins in the eastern part of the settlement could again either speak for traffic through the (by that time already abandoned?) town, the search for spolia for nearby late constructions (mainly the Late Roman fortress and watch towers) ${ }^{107}$ but could also mark the late use of the eastern extremity of the town in the Late Roman period (Early Christian basilica, cemetery, chapel, watch tower and supposed late settlement around the watch tower - see below). The presence of the few fourth century coins at the Symphorus Mithraeum by the Southern town wall might be explained again by people "working" here - in either the mithraeum itself or along the town wall - in search of spolia. ${ }^{108}$ Fresh and promising data could be gathered on the late history of the Civil Town from recent research and evaluation of old excavations of the cemeteries around the settlement. ${ }^{109}$ Taking into account all the cemeteries of the Civil Town known to date (southwest, south, west and east of the Civil Town as well as a lonely burial in the eastern part of the settlement) Gábor Lassányi és Lóránt Vass have concluded that the latest burials date between the second half of the third-beginning of the fourth century. Even the recently found antler comb, possibly one of the latest grave goods from the Eastern Cemetery did not prove to be dated later than the middle of the fourth century. Graves established later than this date can only be securely identified North of the Eastern Cemetery, in the neighbourhood of a watchtower (excavated in the nineteenth century) and the Danube harbour (?) and may possibly belong to the population living in this area in the Late Roman Period. ${ }^{110}$$$
* * *
$$

106 57.53.1: AE3, fourth century.

${ }^{107}$ Spolia used for the Late Roman fortress in Aquincum: Kocsis 2001, 71-72. Further carved stones (mainly from the Civil Town's cemeteries) reused in the construction of watchtowers nearby:

${ }^{108}$ Spolia were used from mithraea too: a relief depicting Sol - as well a building inscription - reused as paving slabs in the fourth century, derive from Mithraeum IV. in Poetovio: HORvaT et al. 2003, 162. Further evidence for temples being mined for spolia in the fourth century: WALSH 2016, 231-232.

${ }^{109}$ LASSÁNYI-VASS 2015, 169-187.

${ }^{110}$ Op. cit. 2015, 174-175.
} BUDAI BALOGH 2011, 61, with further reading. 
As seen above, recent research in and around the Civil Town do not confirm the presence of fourth century occupation of the settlement and even the old data from a possible late phase ${ }^{111}$ can be explained in the light of these more modern discoveries.

In the case of the macellum, L. Nagy observed "weak buildings with adobe walls from the fourth century". ${ }^{112}$ However, during revaluation of the old documentation (see above) these features turned out to be thin, poor quality partition walls from the southern rooms of the market building itself. Based on its relative chronological position (Phase 5) as well as the find materials - the macellum can be dated between the middle-end of third century AD. ${ }^{113}$ The same could be said about K. Póczy's identification in the early fourth century reconstructions along the western façade of the building. ${ }^{114}$ The famous inscription (cited several times above) dated between AD 305-308 naming the duoviri of Aquincum for the last time, was found in the canabae, thus - as T. Nagy rightly pointed out ${ }^{115}$ - the inscription should not be associated with the Civil Town or used as a reference point for declining municipal life at the settlement.

Out of the three cicada brooches that were reportedly connected to the Civil Town (thus, considered evidence for Late Roman occupation of the town), only one can securely be indentified as coming from a documented context. ${ }^{16}$ This piece was found by T. Nagy during the excavation of the so-called Symphorus Mithraeum and its surroundings. According to the excavator, the fibula was found in the "uppermost, fourth century layer" North of the mithraeum, but in the same sentence he notes that it was " $-76 \mathrm{~cm}$, below the highest floor level". ${ }^{117}$ Since this contradiction is very hard to resolve (if it was in the uppermost layer, then how could it be below the latest floor at the same time?) its context, thus, remains uncertain (perhaps it is a stray find from the topmost layer?). ${ }^{118}$

The coin of Constantius II, found in the half-filled late fossa below a fallen segment of the Southern town wall by P. Zsidi ${ }^{119}$ needs reconsideration too: a coin from such a context could only provide information (namely t.p.q. data) to the falling of that segment of the wall but not to its rebuilding phase, thus, it is no proof that there was a fourth century phase in the Western part of the Civil Town. The absence of fourth century occupation here is further supported by the fact that only a few fourth century coins were discovered in this previously not excavated area. ${ }^{120}$

Considering the supposed fourth century-phase of North-South running main aqueduct (or its underground successor) and the possible Late Roman fortification around the springs feeding the water conduit (at the so-called Roman Bath), ${ }^{121}$ it must not be forgotten that not only did the aqueduct supply the town but was preliminary constructed to serve the legionary fortress, ${ }^{122}$ thus, providing for its further operation was essential even if it was no longer used (or only on a very limited scale) by the occupants of the Civil Town. Nevertheless, it is also worth considering that - based on the find material $-\mathrm{K}$. Póczy dates the end of the sacral use of the springs sometime around the second decade of the fourth century. ${ }^{123}$

Apart from the research of recent years, a few earlier statements and observations also questioned the fourth century occupation of the area. During his study of the collegia in the Civil Town, T. Nagy declared that there is no data to show they were active after $\mathrm{AD} 315^{124}$ and no trace of fourth century industrial activity can be observed here either. ${ }^{125}$ Even K. Póczy - who in turn did suppose a fourth century phase for some parts of the Civil Town (see above) - noted that there are no fourth century finds from the settlement. She also considered that information concerning the fourth century history of the Civil Town are very scarce and even if all fourth century-pavements were removed during the nineteenth century, some Late Roman finds should still be found in the museum's collection. Finally, K. Póczy concluded - an idea which has been supported by recent observations by G. Lassányi and L. Vass as well (see above) - that the remaining (?) population must have moved closer to the neighbouring watchtower

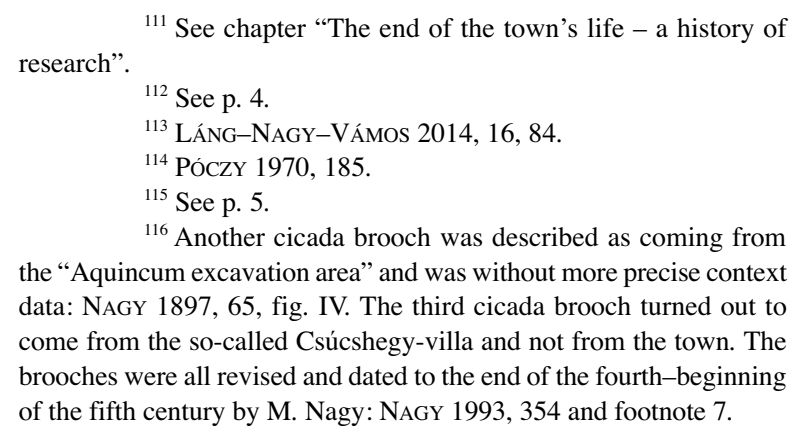

${ }^{117}$ NAGY 1943, 389, fig. 28.

${ }^{118}$ According to the excavation documentation from T. Nagy, the brooch was found $-70 \mathrm{~cm}$ below ground level, i.e. it could not have come from the latest layer! BHM - AA H-2990-2013.

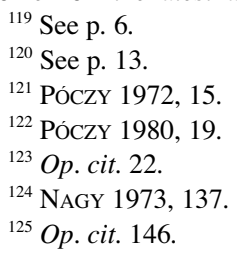


by the Danube (the so-called "Gas Factory watchtower"). ${ }^{126}$ The presence of both the so-called Early Chirstian „Double Basilica” and the chapel with the cemetery could be explained with such a small community living east of the former Civil Town.

Finally, what could be the reasons behind the - possibly peaceful ${ }^{127}$ - abandonment of the Aquincum Civil Town? These reason may be sought in the, by that time, already rundown fortifications, the fact that the settlement must have been exposed to Barbarian raids ${ }^{128}$ and - probably as a consequence - the loss of markets. ${ }^{129}$ Where did the inhabitants go and settle later? Logically, most of the inhabitants might have gradually moved to the canabae in hope of a safer life and better living, ${ }^{130}$ while a Late Roman settlement could be predicted east of the Civil Town on the Danube banks, possibly related to the presence of the watchtower here. Some of the population might also have moved into the hills to the former villa estates, as observed for the villas at Csúcshegy or Békásmegyer in the Buda hills ${ }^{131}$ or more recently at the so-called Harsánylejtö villa. Here, little more than $3 \mathrm{kms}$ from the centre of the Civil Town, recent excavations revealed truly fourth century find material with a Late Roman lamp, Tokod glazed ware, pots with incised net pattern and 106 coins of which $98 \%$ (!) could be dated to the fourth century (mainly coins of the Constantinus dynasty); the type of finds that are completely missing from the Civil Town. ${ }^{132}$

\section{ANALOGIES}

The surprisingly short life of the Aquincum Civil Town is not unparalleled among Roman settlements associated with legions or other troop units in Pannonia or the European provinces. The vicus of the Albertfalva auxiliary fort (Pannonia Inferior) - close to Aquincum - was abandoned towards the middle third of the third century. ${ }^{133}$ Life in the Civil Town of Brigetio (Pannonia Inferior) also seems to end towards the end of the third century: coins of Severus Alexander and Gordian III were discovered in building debris and the latest renovations could have taken place during the reign of Emperor Aurelianus and Probus. According to recent research, the settlement was already abandoned in the fourth century. ${ }^{134}$ The same process could be observed in the Civil Town of Vindobona (Pannonia Superior), where the settlement "shrank" in the middle of the third century and later was completely abandoned. ${ }^{135}$ Not only civil towns but also canabae (or at least some of them) cease to function after the third century: parts of the Aquincum Military Town were also abandoned ${ }^{136}$ and used as cemeteries at the end of the third century. The same process of abandonment can be observed at the canabae of Brigetio. ${ }^{137}$ The case of Carnuntum (capital of Pannonia Superior) is exceptional: while the area of the canabae shrank (and some areas were possibly abandoned) from the beginning of the fourth century onwards, ${ }^{138}$ life in the Civil Town continued and saw the late use of the Palastruine. In addition, the residental quarter of Schloss Traum and even parts of the town wall were renovated (though the walls probably surrounded a reduced area). ${ }^{139}$ The situation is similar outside Pannonia too: the military vicus south-west of South Shields was abandoned around AD 260-270 ${ }^{140}$, which is not an exceptional phenomenon among the vici of forts on Hadrian's Wall (and elsewhere in Northern England) ${ }^{141}$. The reason for this process lies in the fact that the economic basis of these vici disappeared as a result of the declining number of soldiers in the forts - a situation very similar to the Aquincum Civil town (i.e. loosing of market). ${ }^{142}$

\footnotetext{
${ }^{126}$ See footnote 45 .

${ }^{127}$ No data of the above-mentioned excavations refer to destruction or fire, except in the case of the "Painter's House". See also footnote 76 .

${ }^{128}$ Recent summary of B. Grammer on Pannonian town development during the period of the Barracks Emperors - comparing the provincial capitals of Aquincum and Carnuntum - arrives at a similar conclusion. According to him, both the Aquincum Military and Civil Town may have shrunk dramatically between the second halfend of the third century. He did not necessary connect the process to any kind of military conflict, but rather the military reforms and the dislocations of troops from the limes zone: GRAMMER 2015, 54, 57.

${ }^{129}$ B. Grammer comes to a similar conclusion: Op. cit. 57.

${ }^{130}$ ZSIDI 2004, 205

${ }^{131}$ PócZy 1971, 91, 96, 99.
}

${ }^{132}$ LÁNg 2009b, 79-80.

${ }^{133}$ BESZÉDES 2011, 60.

${ }^{134}$ Dobosi 2014, 28; BorHY-Bartus et al. 2011, 51.

${ }^{135}$ MÜLLER-Mader et $a$. 2011, 39.

${ }^{136}$ ZsIDI 2004, 183. and footnote 110 . Recently summarized by: GRAMMER 2015, 37-39, 41.

${ }^{137}$ Dobosi 2014,10 . It was probably completely abandoned.

${ }^{138}$ GRAMMER 2015, 18, 30, 34, 57-58.

${ }^{139}$ Op. cit. 21-22, 32-33. He also calls attention to the discrepancy between the missing fourth century ceramic finds and the rich coin finds from the same period.

${ }^{140}$ SNAPe-Bidwell-Stobis 2010, 43, 52.

${ }^{141}$ Op.cit. 127 and Bidwell-Hodgson 2009, 33-34.

${ }^{142}$ See previous footnote. 
As already mentioned above, the reason for the abandonment of these civil towns should be sought in the escalating military situation from the AD 260 s onwards ${ }^{143}$ when the inhabitants must have felt safer living closer to the well-protected fortresses and the troops, instead of living in towns mostly with their already demolished fortifications. ${ }^{144}$ On the other hand, since canabae were not only the military in character but also the administrative centres of settlement-complexes (Aquincum, Brigetio and, Vindobona) they could have generated an effective demand and market for merchants and craftspeople.

\section{CONCLUSION}

The last period at the Aquincum Civil Town has long been a matter of dispute. As mentioned above, Aquincum researchers were all engaged with the topic. Based on their research, evidence spoke for fourth century occupation phase at the settlement. These data included the several times cited inscription dated to AD 305-308, a late fourth century coin hoard discovered in the so-called Victorinus Mithraeum, "houses with weak, adobe walls" in the southern part of the macellum, cicada brooches which are also considered evidence for late settlers in the town and a coin of Constantius II found in a half-filled fossa below a fallen segment of the Southern town wall. Apart from these, archaeologists' observations concerning any late building acitivity were concentrated along the main North-South road of the settlement, the former limes road that remained in use even after the Roman Period and even nowadays serves as a main road. A frequent explanation for the obvious paucity of Late Roman finds (also noted by scholars apart from their ideas on the existence of a fourth century-phase) in this area was that the first excavations in the nineteenth century must have destroyed the latest (namely the fourth century) layers and features.

In any case, new excavation results and revaluation of old materials showed that most "Late Roman" finds turned out to be third century finds and walls that were previously commonly identified as "fourth century walls" turned out to belong to third century construction phases. The previously favored idea of the fortified western part of the settlement surviving into the fourth century cannot yet be demonstrated - results of an extensive and systematic metal detecting survey only produced seven, fourth century coins (out of a total of 68 coins). Small-scale excavation related to this project (carried out in an undisturbed area) also only brought to light third century finds. Further evidence for the absent fourth century phase is the presence of the so-called "dark earth" phenomenon, which has only been observed in the western part of the settlement so far. Here, a layer with third century finds is located below this black layer indicating the abandonment of the settlement. Even though, this dark layer is so far completely missing in the eastern part of the town, the latest Roman layers that can be dated to the middle-end of the third century, all appear below the present ground level or recent filling layer. Based on recent data from the above-mentioned excavations, the latest observable period in the Civil Town falls in the middle-end of the third century. Such an early abandonment of the Aquincum Civil Town has other parallels among Pannonian towns: the civil settlements of Brigetio, Vindobona or the canabae of Carnuntum and military vicus of Albertfalva all seem to end around the end of the third century.

And why was the Aquincum Civil Town abandoned relatively early? The reasons might be sought in the, by that time, already deteriorated fortifications (thus, exposing the settlement to Barbarian raids) and the loss of markets. The former inhabitants probably moved gradually to the canabae in hope of a more secure existence and better living, while a Late Roman settlement may have been established East of the Civil Town on the Danube bank, possibly connected to the watchtower. Some of the population may also have moved into the hills to the former villa estates, as has been observed at the Csúcshegy, Békásmegyer, and Harsánylejtő villas.

In sum, and as far as is known at present - the latest, urban period at the Aquincum Civil Town dates to the end of the third-beginning of the fourth century. This is the last date when the settlement could have still functioned as a proper colonia with public administration and infrastructure. No further (systematic) use could be demonstrated here in layers, finds, or constructions. Nevertheless, since a few fourth century finds still occur (coins, cicada brooch, coin hoard), the possibility cannot be excluded that certain areas - possibly chiefly along the main

${ }^{143}$ Mócsy 1974, 263-265. B. Grammer rather connects the process to the military reforms and dislocations of the troops along the Pannonian frontier during the period of the Barracks Emperors, see footnotes 129-130.
${ }^{144}$ In case of the Aquincum Civil Town, the Eastern and Southern fortifications could have been partially or completely unused by the middle of the third century AD: LÁNG 2011b, 23-24, and LÁNGLASSÁNYI 2014, 29. 
roads - were still sporadically used. Since life went on in and around the Late Roman fortress only ca. two kilometers to the South and to the East, around the neighbouring fourth century watchtowers situated along the Danube bank (e.g. "Nánási Road" and "the Gas Factory" burgi) spolia from all over the settlement-complex were removed and used in later construction. It is even possible that occasional settlers occupied with stone-mining from earlier structures could have stayed in the mostly ruined Civil Town during the fourth century. As further excavations (especially in the western part of the settlement) and revaluation of other old excavation materials are also in progress, it is hoped more information on the mysterious last phase of the Civil Town will be revealed.

\section{REFERENCES}

ALFÖLDI 1942

BESZÉDES 2011

BidWELL-HodGSON 2009

Bíró-TOMKA 2013

BESZÉDES-SZILAS 2007

BORHY-BARTUS et al. 2011

BudAI BALOGH 2011

DIVALD 1910

DoBosi 2014

GRAMMER 2015

GROH et al. 2014

HORVAT et al. 2003

KeLemEN 2017

Kocsis 2001

KUZSINSZKY 1889

KUZSINSZKY 1934

LASSÁNYI 2013

LASSÁNYI-VASS 2015

LASSÁNYI-ZSIDI 2014

LASSÁNYI-ZSIDI 2015
= A. ALFöLDI: Aquincum későrómai világban [Aquincum in the late antique world]. In: Budapest története [The History of Budapest] I. Ed.: K. Szendy. Budapest 1942, 670-746.

= J. BESZÉDES: Az albertfalvi tábor és település kutatásának eredményei Nagy Tibor után (Ausgrabungsergebnisse von dem Römischen Lager und der Siedlung in Albertfalva nach der Tätigkeit von Tibor Nagy). BudRég 44 (2011) 58-74.

= P. BidwelL-N. Hodgson: The Roman Army in Northern Britain. Newcastle upon Tyne 2009.

= Sz. Bíró-P. ToмкA: A Györ, Széchenyi téri fekete réteg rejtélyei [The mysteries of the black layer at the Széchenyi Square, Győr]. In: Csóka úrtól Gáspár atyáig. Ünnepi kötet Csóka Gáspár OSB 75. születésnapjára. Györ 2013, 521-538.

$=\mathrm{J}$. BESZÉDES-G. SZILAS: Excavation of prehistoric and Roman period sites along the route of the M6 highway in 2006. AqFüz 13 (2007) 233-273.

= L. BorhY-D. Bartus-Z. CZAJLIK-L. RuPNIK-E. SzÁmadó: Brigetio (Komárom/Szőny): Fortress - City next to the Danube. In: Romans in the Danube. The Ripa Pannonica in Hungary as a World Heritage Site. Ed.: Zs. Visy. Pécs 2011, 42-51.

$=$ T. BudAI BALOGH: A Valentinian Period burgus on Római part. AqFüz 17 (2011) 52-64.

$=\mathrm{K}$. DivaLD: Budapest művészete a török hódoltság előtt [The Art of Budapest before the Turkish Occupation]. Budapest 1910.

= L. DoBosi: Városi lakóházépítészet Brigetioban. A Komárom/Szőny-Vásártér lelőhely 1992-2013 között folytatott ásatások építészeti vonatkozású eredményei (Roman Houses in the Municipium of Brigetio. The results of the excavations at Komárom/Szőny-Vásártér between 1992-2010 from an architectural point of view). Acta Archaeologia Brigetionensia 1/6. Komárom 2014.

= B. Grammer: Stadtentwicklung in Pannonien während der Soldatenkaiserzeit. CarnuntumJb 2015, $11-70$.

= S. GROH-O. LÁNG-H. SedLMAYER-P. Zsidi: Neues zur Urbanistik der Zivilstädte von Aquincum Budapest und Carnuntum-Petronell. ActaArchHung 65 (2014) 361-404.

= J. Horvat-M. LovenJaK-A. Dolenc Vičič-M. LubŠINA-TuŠEK-M. Tomanič-JeVRemov-Z. Šubic: Poetovio. Development and topography. In: The Autonomous Towns of Noricum and Pannonia. Eds: M. Šašel Kos, P. Scherrers. Situla 41. Ljubljana 2003, 153-189.

= Zs. KELEMEN: Az aquincum polgárvárosi, XXIX. számú lakóház hitelesítő feltárásának üvegleletei 2004-2007. ELTE-BTK Régészettudományi Intézet. Publikálatlan alapszakos szakdolgozat [Dwelling house nr. XXIX in the Aquincum Civil Town, glass finds from control excavations carried out between 2004 and 2007. ELTE-BTK Institute of Archaeological Science. Unpublished BA thesis.] Budapest 2017.

= L. Kocsis: Die Südostecke des Legionslagers von Aquincum aus dem 2-3. Jahrhundert und der daran angrenzende Mauerabschnitt der spätrömischen Festung. BudRég 34 (2001) 71-78.

$=$ B. KuzsinszKY: A legújabb aquincumi ásatások 1887-1888 [The latest excavations in Aquincum 1887-1888]. BudRég (1889) 39-170.

$=$ B. KuZsINSZKY: Aquincum. Ausgrabungen und Funde. Budapest 1934.

$=$ G. LASSÁNYI: Research in the territory of the future baseball park west of the Civil Town of Aquincum. AqFüz 19 (2013) 19-31.

= G. LASSÁNYI-L. VASS: Az ,utolsó rómaiak" - adatok Aquincum polgárvárosának kései történetéhez egy agancsfésü kapcsán (The "last Romans" - new data to the Late Roman history of the Aquincum Civil Town as it is revealed by an antler comb). BudRég 48 (2015) 169-187.

= G. LASSÁNYI-P. ZsIDI: Budapest, III.ker. Aquincum Polgárváros Nyugati oldal (Hrsz.: 19668/4) [Budapest, $3^{\text {rd }}$ distr., Aquincum Civil Town, West. Parcel no. 19668/4]. AqFüz 20 (2014) 127-128.

$=$ G. LASSÁNYI-P. ZsIDI: Preliminary report on the non-invasive, instrumental survey, excavation and archaeological site protection works in the territory of the Civil Town in Aquincum. AqFüz 21 (2015) 51-57. 
LÁNG 2003

LÁNG 2008

LÁNG 2009a

LÁNG 2009b

LÁNG 2010

LÁNG 2011a

LÁNG 2011b

LÁNG 2012a

LÁNG 2012b

LÁNG 2013

LÁNG 2016a

LÁNG 2016b

LÁNG - LASSÁNYI 2014

LÁNG-LASSÁNYI 2015

LÁNG-NAGY-VÁMOS 2014

MADARASSY-TOPÁL- ZSIDI 2000

MóCSY 1974

MÜLLER-MADER et al. 2011

NAGY 1897

L. NAGY 1942

NAGY 1942

NAGY 1943

NAGY 1948

NAGY 1958

NAGY 1973

NAGY 1993

NÉMETH 1823

NÉMETH-HAJNÓCZI 1976
= O. LÁNG: Reconsidering the Aquincum macellum: analogies and origins. ActaArchHung 54 (2003) 165-204.

= O. LÁNG: Functions and Phases: the „Peristyl-House” in the Civil Town of Aquincum. In: Domus. Das Haus in den Städten der Römischen Donauprovinzen. Hrsg.: P. Scherrer. Wien 2008, 271-284.

$=$ O. LÁNG: Richly decorated building in the western part of the Civil Town of Aquincum. AqFüz 15 (2009) 17-28.

= O. LÁNG: Late Roman building complex in the territory of Harsánylejtő. AqFüz 15 (2009) 75--85.

= O. LÁNG: 16. Budapest, III. ker., Szentendrei út 133, volt MHSZ Lőtér, Aquincum-polgárváros, Hrsz.:19343/8 [Budapest, $3^{\text {rd }}$ distr., 133 Szentendrei road, former MHSZ shooting range, Aquincum Civil Town, parcel no. 1933/8]. Aqfüz 16 (2010) 188-190

= O. LÁNG: The "Painter's house" in Aquincum: old data and new results. BudRég 44 (2011) 32-44.

$=$ O. LÁNG: Control excavation on the territory of the so-called Painter's House and its surroundings by the southern town wall of Aquincum Civil Town. Aqfüz 17 (2011) 18-35.

= O. LÁNG: Urbanistic problems in the Civil Town of Aquincum: the so-called "Northern stripe". ELTE Faculty of Arts, PhD School of History Science, Archaeological PhD. Unpublished PhD dissertation. Budapest 2012. (in Hungarian)

$=$ O. LÁNG: New results in research in the southeastern part of the Civil Town in Aquincum - the socalled "Painter's House" and its surroundings. AqFüz 18 (2012) 17-36.

= O. LÁNG: Is it the basilica? New data on Building no. I. in the Aquincum Civil Town. CarnuntumJb 2013, 99-115.

$=$ O. LÁNG: Industry and commerce in the city of Aquincum. In: Urban Craftsmen and Traders in the Roman World. Eds: A. Wilson, M. Flohr. Oxford 2016, 352-377.

$=$ O. LÁNG: "Strip house with an atrium - residence wing": authenticating excavation in the northeastern part of the Aquincum Civil Town IV. AqFüz 22 (2016) 47-59.

$=$ O. LÁNG - G. LASSÁNYI: New data on the use of the Western and Eastern outskirts of the Civil Town: the renovation of the Budapest-Esztergom railway line. AqFüz 20 (2014) 16-37.

$=$ O. LÁNG-G. LASSÁNYI: New data on the central area of the Civil Town of Aquincum: the reconstruction of the Budapest-Esztergom railway line II. AqFüz 21 (2015) 19-31.

$=$ O. LÁNG-A. NAGY-P. VÁmOS: The Aquincum macellum. Researches in the area of the macellum in the Aquincum Civil Town (1882-1965). Aquincum Nostrum I/3. Budapest 2014.

= O. MADARASSY-J. TopáL-P. ZsidI: Frühchristliche Grabkapellen und Bestattungen in Aquincum. In: Frühchristliche Denkmäler in Aquincum. Sonderausstellung des Aquincum Museums des HMB aus Anlass des Millenniums. Budapest 2000, 29-44.

= A. MócsY: Pannonia and Upper Moesia. Provinces of the Roman Empire. London 1974.

= M. MÜLleR-I. MADER-R. Chinelli-S. JÄGER-WERSONIG-S. SAKL-ObERTHALER-U. EISENMENGERS. Czeika-C. Litschauer-Chr. Öllerer-E. Eleftheriadou: Entlang des Rennwegs. Die römische Zivilsiedlung von Vindobona. Wien 2011.

$=$ G. NAGY: Budapest a népvándorlás korában [Budapest in the Migration Period]. BudRég 5 (1897) $55-94$.

= L. NAGY: Kereszténység és kontinuitás [Christianity and continuity]. In: Budapest története I [The History of Budapest]. Ed.: K. Szendy. Budapest 1942, 765-778.

$=\mathrm{T}$. NAGY: Vallási élet Aquincumban [Religious life in Aquincum]. In: Budapest története I [The History of Budapest]. Ed.: K. Szendy.Budapest 1942, 386-463.

= T. NAGY: A Fővárosi Régészeti és Ásatási Intézet jelentése az 1938-1942 évek között végzett kutatásairól [Report of the Archaeology and Excavation Institute of the Capital on researches between 1938-1942]. BudRég 13 (1943) 359-399.

= T. NAGY: A modern szállodák egy antik elöde Aquincumból [An antique predecessor of modern hotels from Aquincum]. Új Építészet 3 (1948) 121-122.

= T. NAGY: Az aquincumi ún. Festölakás [The so-called Painter's House in Aquincum]. BudRég 18 (1958) 149-189.

= T. NAGY: Budapest története az őskortól az Árpád-kor végéig. II: Római kor [The history of Budapest from Prehistory to the end of the Árpád era II. Roman period]. In: Budapest története I. [History of Budapest]. Ed.: L. Gerevich. Budapest 1973, 83-216.

= M. NAGY: Óbuda a népvándorlás korban (Óbuda zur Zeit der Völkerwanderung). BudRég 30 (1993) 353-395.

= S. NÉMETH: I. Értekezések. Németh Sándornak, az előtt Gubernialis Tanátsodnak, most pedig Ó-Buda, és Visegrád Kir. Korona Uradalmak Kameralis Praefectusának észrevételei az Ó-Budai Határban található, és látható Római Régiségek eránt. TGy 7 (1823) 3-20.

= M. NÉmeTH-Gy. HaJNóczi: Nr.111., III. Szentendrei út 139. In: M. Kaba: Works of rescue and planned excavations conducted by the Historical Museum of Budapest in the years 1971-1975. BudRég 24 (1976) 423. 
РETŐ 1976

PETŐ 1984

PócZY 1964

PócZY 1967

PócZY 1970

PócZY 1971

PócZY 1972

PócZY 1976

PócZY 1980

PócZY 1996

PócZY 1998

PócZY 2000

PócZY 2003

PócZY 2004

PócZY-HAJNócZI 1968

PócZY-Zsidi 2003

RÓMER 1863

RÓMER 1875

SNAPE-BIDWELL-STOBBS 2010

То́тн 1980

То́тн 2009

VARGA 2010

WALSH 2016

ZSIDI 1984

ZsIDI 1990

ZSIDI 1994

ZsIDI 1997-1998

ZSIDI 1998

ZSIDI 2002A

ZSIDI 2002b

ZSIDI 2004
= M. PeTő: 53/34. Záhony-Sujtás utca. RégFüz 29 (1976) 32.

= M. PETÕ: Archäologische Forschungen auf dem Gebiet der Kaszás-dülő. BudRég 25 (1984) 275-290.

= K. PóczY: Aquincum im 4. Jahrhundert. BudRég 21 (1964) 55-78.

= K. Póczy: Municipium und Canabae in Aquincum. In: Studien zu den Militärgrenzen Roms. Vorträge des 6. Internazionalen Limeskongresses in Süddeutschland. Köln-Graz 1967, 151-156.

$=\mathrm{K}$. Póczy: Anwendung neuerer Ausgrabungergebnisse bei der Ruinenkonservierung in der Bürgerstadt Aquincum. ATASH 67 (1970) 177-194.

= K. PóczY: A békásmegyeri villa és az Aquincumi környéki gazdaságok a markomann háborúk után (Die Villa von Békásmegyer und die Gutshöfe in der Umgebung von Aquincum nach den Markomannenkrigen). BudRég 22 (1971) 85-102.

= K. Póczy: Aquincum első aquaeductusa (Le premier aqueduc d'Aquincum). ArchÉrt 99 (1972) $15-32$.

= K. Póczy: 53/37. Keled u. RégFüz 29 (1976) 33.

= K. PóczY: Szent kerületek Aquincum és Brigetio aquaeductusánál (Sanctuaries près des aqueducs d'Aquincum et de Brigetio). ArchÉrt 107 (1980) 3-165.

= K. PócZY: Aquincum a honfoglalás idején. Mit talált Árpád fejedelem 896-ban „Attila városá”-ból Óbudán? Kamarakiálltás az Aquincumi Múzeumban 1996. szeptember 12-től október 31-ig [Aquincum at the Time of the Hungarian Conquest. What did Prince Árpád find of "Attila's town" in Óbuda in 896?] Budapest 1996.

= K. PóczY: A pannóniai késő császárkori múmiatemetkezések néhány tanulsága [A few lessons to be drawn from Late Roman Imperial Period mummy burials in Pannonia]. BudRég 32 (1998) 59-75.

$=$ K. Póczy: Frühchristliche Kirchen in Aquincum. In: Frühchristliche Denkmäler in Aquincum. Sonderausstellung des Aquincum Museums des HMB aus Anlass des Millenniums. Budapest 2000, $19-28$.

= K. PócZY: Wasserver- und entsorgung, Gebäude des Stadtzentrums. In: Forschungen in Aquincum 1969-2002. Hrsg.: P. Zsidi. Budapest 2003, 144-149.

= K. PóczY: Aquincum, Budapest római kori történelmi városmagja [Aquincum. The Roman historical urban core of Budapest]. Budapest 2004

= K. Póczy-Gy. HaJNóczi: 29. RégFüz 21 (1968) 22-23.

= K. PócZY-P. ZsidI: Zur Frage der Kontinuität in Aquincum. In: Forschungen in Aquincum 19692002. Hrsg.: P. Zsidi. Budapest 2003, 63-72.

= F. RÓMER: Pannonia területén Magyarországban fennmaradt néhány római várnáról. ArchKözl 3 (1863) 35-56.

= F. RÓMER: O-budai ásatások [Excavations in Ó-buda]. ArchÉrt 9 (1875) 111-113.

$=$ M. SNAPE-P. BIDWELL-G. STOBBS: Excavations in the Military Vicus south - West of the Roman fort at South Shields in 1973, 1988 and 2002. Arbeia Journal 9 (2010) 43-132.

= E. TóтH: Vitás kérdések Pannonia 4. századi történetében. I.: Contra Acinco et Bononia [Disputes in the fourth century history of Pannonia I. Contra Acinco et Bononia]. AT 27 (1980) 131-137.

$=$ E. Tо́тн: Studia Valeria. Az alsóhetényi és ságvári későrómai erődök kutatásának eredményei [Results of the [Researches of the Late Roman] Forts of Alsóhetény and Ságvár]. Dombóvár 2009.

= G. VARGA: Roman mortaria from Salla. ActaArchHung 61 (2010) 145-184.

= D. WALSH: The fate of temples in Noricum and Pannonia. AJA 120/2 (2016) 221-238.

= P. ZsIDI: 21. Aquincum polgárváros. Hrsz.: 19418, 19430,19695 [21. Aquincum Civil Town. Parcel no.: 19418,19430,19695]. BudRég 25 (1984) 461-462.

= P. ZsIDI: Aquincum polgárvárosának városfala és védművei az újabb kutatások tükrében (Stadtmauer und Verteidigungssystem der Zivilstadt von Aquincum im Spiegel der neuesten Forschungsergebnisse). ComArchHung 1990, 143-169.

$=$ P. ZsIDI: Aquincum - the capital of Pannonia Inferior. Topography of the Civil Town. In: La Pannonia e L'impero Romano. Ed.: G. Hajnóczi. Roma 1994, 213-220.

= P. ZsIDI: The question of continuity in Aquincum, the capital of Pannonia Inferior. Antaeus 24 (1997-1998) 585-592.

= P. ZsIDI: Az aquincumi tüzoltók kollégiuma és a tüzoltószékház [The collegium of the Aquincum fire brigade and their headquarters]. BudRég 32 (1998) 91-97.

= P. ZsIDI: Aquincum polgárvárosa [The Aquincum Civil Town]. Budapest 2002.

$=$ P. ZsIDI: Verifying excavation in the so-called Symphorus mithraeum of the Aquincum Civil Town. AqFüz 8 (2002) 38-48.

= P. ZsIDI: Aquincum topográfiája [The topography of Aquincum]. SpecN 18 (2004) 167-226. 